\title{
Quantity in Old Norse and modern peninsular North Germanic
}

\author{
Gjert Kristoffersen
}

Received: 1 July 2009 / Accepted: 11 April 2010 /Published online: 8 February 2011

(C) The Author(s) 2011. This article is published with open access at Springerlink.com

\begin{abstract}
This article discusses the transition from a system with contrastive, segmental quantity in Old Norse into the present day system characterizing most Norwegian and Swedish dialects, where stressed syllables are obligatorily bimoraic. Starting with variation within East Norwegian, two intermediate varieties between Old Norse and the modern system are identified, and the four varieties are then related to each other by means of constraint reranking within an Optimality Theory analysis. A full factorial typology based on the four constraints involved is then developed. This renders four possible intermediate stages between Old Norse and the modern system, of which two are attested in East Norwegian. When the scope subsequently is widened to all varieties of Norwegian and Swedish, it is shown that all the intermediate varieties predicted by the analysis are attested. More importantly, no other varieties than those predicted seem to exist, even if such varieties can be construed. This suggests that the grammar developed to account for the changes not only is empirically adequate, but also has explanatory value.
\end{abstract}

Keywords Phonology $\cdot$ Syllable quantity $\cdot$ Stress $\cdot$ Language change $\cdot$ North Germanic

Compared to their ancestor Old Norse, modern Norwegian and Swedish have undergone radical changes with respect to prosodic structure. ${ }^{1}$ While stress was consistently assigned to the initial syllable, or "root" syllable, in Old Norse, modern

\footnotetext{
${ }^{1}$ This also holds for the other North Germanic languages Danish, Faroese, and Icelandic. In the following, I use the term 'Peninsular North Germanic' to distinguish Norwegian and Swedish from (non-peninsular) Danish. For practical reasons I shall also use Old Norse as a cover term for Old Norwegian and Old Swedish, even if the term Old Norse usually is used for Old Norwegian and Old Icelandic only.
}

Electronic supplementary material The online version of this article (doi:10.1007/s10828-010-9041-9) contains supplementary material, which is available to authorized users.

G. Kristoffersen $(\bowtie)$

Department of Linguistic, Literary and Aesthetic Studies, University of Bergen, Bergen, Norway

e-mail: Gjert.Kristoffersen@1le.uib.no

URL: http://www.uib.no/personer/Gjert.Kristoffersen 
continental North Germanic has developed a more Latin-like stress system where stress falls on one of the three final syllables of the word (Bruce 1998; Kristoffersen 2000). In addition, most dialects of Norwegian and Swedish have developed contrastive (lexical) tonal accent (Gårding 1977; Bruce and Gårding 1978). This means that a primary stressed syllable will have one of two contrastive melodies, usually referred to as accent 1 and accent 2 . The development of these tonal accents corresponds to the development of the so-called 'stød' in Danish (Basbøll 1998, 2005), a kind of glottal catch that characterizes stressed syllables that in the tonal Norwegian and Swedish dialects are assigned accent 1. Finally, while stress and syllable weight were independent in Old Norse, in the sense that a stressed syllable could be monomoraic, bimoraic, or trimoraic, stressed syllables in most modern North Germanic dialects are obligatorily bimoraic, except in some derived environments where we find trimoraic syllables with the structure $\mathrm{CVVC}_{\mathrm{i}}+\mathrm{C}_{\mathrm{j}} \mathrm{V}^{2}$

It is the latter development, that is, the change with respect to constraints on syllabic quantity as expressed by the number of moras a stressed syllable may consist of, that is the topic of the present paper. While most Norwegian and Swedish dialects manifest what is often referred to as Prokosch's law (Prokosch 1939; see also Riad 1992, 1995), which embodies the requirement that all stressed syllables be bimoraic, some dialects have not fully implemented this change, or at least they had not done so by the mid-twentieth century. As will become clear below, these dialects can be divided into different types in which the Old Norse system - characterized by free combination of segmental quantity in stressed syllables - has been preserved to different degrees.

The aim of the paper is to account for this variation in Peninsular North Germanic by means of Optimality Theory (henceforth OT), the main hypothesis being that the development from Old Norse into Post-Prokosch modern Norwegian and Swedish can be accounted for by reranking of a limited set of constraints. This can again be tied to the hypothesis that in the unmarked cases, language change from an OT perspective amounts to reranking within the same set of constraints.

The theoretical interest in the paper lies in the relationship between the full factorial typology, that is, the set of all possible rankings between the faithfulness and markedness constraints that are held to be involved in the change, and the developments that are in fact attested. A factorial typology represents the set of all possible, empirically different grammars that a given set of constraints allows. By hypothesis, the Old Norse grammar therefore may have developed into all the varieties defined and delimited by the factorial typology.

I shall take as my point of departure the variation found in East Norwegian dialects, which designate the varieties spoken in the eastern and northern part of southern Norway. Having established the grammars and the factorial typology that can be derived from them, we shall widen our perspective to all attested dialects of Norwegian and Swedish in order to look for the predicted varieties not found within the realm of East Norwegian. As we shall see, a perfect match can be established between the six grammars predicted by the analysis and the set of varieties that are empirically attested.

\footnotetext{
${ }^{2}$ An example is the result of adding the preterite marker/-te/to the verbal root/fø:l/, føl- '(to) feel', which is $\left[{ }^{2}\right.$ fø:l.to].
} 
The paper is organized as follows. In section 1, I introduce the East Norwegian dialects to be discussed and the essential data. In section 2, the theoretical apparatus is introduced, and in section 3 the relevant constraint set is discussed. The analysis of the East Norwegian and Old Norse data introduced in section 1 follows in section 4. In section 5 I develop a factorial typology based on the four central constraints of the analysis from section 4. Here I also show that the two predicted types that are lacking in East Norwegian are indeed found in other varieties. The geographical coverage of the analysis is extended to other Swedish dialects, especially FennoSwedish, in section 6. In section 7 I discuss the consequences of including all constraints introduced in section 3 in the factorial typology. The paper is concluded in section 8 .

\section{Varieties and data-East Norwegian}

In this section I introduce the crucial data underlying the analysis of East Norwegian that will follow in section 4 below. It is organized by dialect type. I begin with Old Norse, and then I introduce the two dialect groups where light, stressed syllables are still well-formed. Finally I discuss the metrical system of so-called Urban East Norwegian (Kristoffersen 2000), a representative of the Post-Prokosch type where all stressed syllables must be bimoraic.

Since this study is on quantity, only the core word types involved will be discussed. These are monosyllabic words and disyllabic words with initial stress, that is, with stress on the so-called root syllable. These two types represent the majority of the inherited, Germanic part of the Old Norse lexicon, where roots were generally monosyllabic, and words often disyllabic or trisyllabic due to inflection. ${ }^{3}$

Three basic types of stressed syllables will be posited, distinguished by different quantity as computed across the syllable rhyme as a whole. These are (i) monomoraic syllables, which I shall refer to as light, (ii) bimoraic syllables, which I shall refer to as heavy, and (iii) trimoraic syllables, which will be referred to as superheavy. The heavy, bimoraic type can be divided into two subtypes distinguished by how the weight is realized with respect to segmental structure. The first type is characterized by a long, bimoraic vowel in an open syllable, while the second is characterized by a short, monomoraic vowel followed by a moraic consonant. In disyllabic words, the latter type comes in two subtypes. The first is characterized by an intervocalic consonant group, where the first member constitutes the moraic coda of the stressed syllable (Weight by Position, Hayes 1989, 1995). In the second, characterized by only one intervocalic consonant, weight is secured by consonant gemination. Only the latter type will be included in the data sets here. With respect to quantity, words characterized by Weight by Position do not differ from words characterized by gemination in any relevant ways.

Figure 1 shows the structural differences between the three main syllable types and between the two heavy subtypes, with the weight differences computed in moras

\footnotetext{
${ }^{3}$ The same constraints on quantity that hold for these two minimal types will also hold for longer words of foreign origin, where, in addition, the question of stress placement becomes an issue.
} 
Fig. 1 Stressed syllable types in monosyllabic words distinguished by weight a) Heavy

i) Long vowel

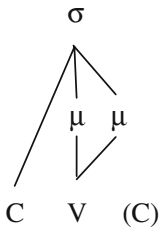

$=\mathrm{CV}_{\mu \mu}(\mathrm{C})$ b) Light

c) Superheavy

ii) Moraic C
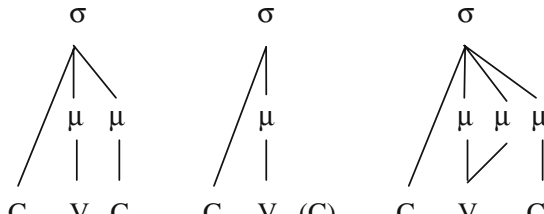

C V (C)

C $\mathrm{V} \quad \mathrm{C}$

$=\mathrm{CV}_{\mu}(\mathrm{C}) \quad=\mathrm{CV}_{\mu \mu} \mathrm{C}_{\mu}$

(Hyman 1985; Hayes 1989). The final line of the figure shows how the structures will be linearly abbreviated in the tabular data overviews and the OT tableaux that follow in subsequent sections. A subscripted mora sign ( $\left.{ }_{\mu}{ }^{\prime}\right)$ marks a segment as moraic.

Note that open syllables in monosyllabic words may be followed by an extrametrical consonant, designated by parentheses in Fig. 1. These will syllabify as onsets in cases where a vowel initial suffix is added.

The corresponding disyllabic structures are shown in Fig. 2. In the structures with a moraic consonant, the result of adding another vowel is a geminate, in that the moraic consonant will also be parsed as an onset with respect to the second syllable headed by the added vowel (see, e.g., Davis 2003). Stress on the initial root vowel has been marked by means of a subscripted 's', and syllable boundaries have been marked with the customary dot in the linear transcriptions.

Fig. 2 Stressed syllable types in disyllabic words distinguished by weight a) Heavy

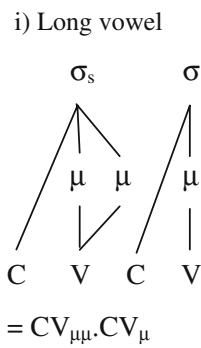

b) Light

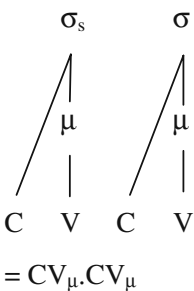

ii) Geminate

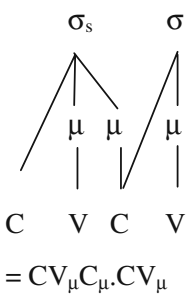

c) Superheavy (long vowel + geminate)

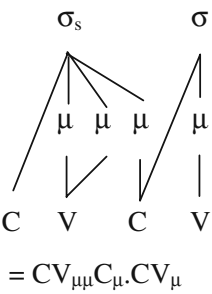




\subsection{Old Norse}

Table 1 shows the range of variation with respect to quantity in monosyllabic as well as disyllabic content words in Old Norse (henceforth ON). ${ }^{4}$ What the Old Norse data essentially show is that within a stressed syllable segmental quantity can combine freely, and that quantity is contrastive at the segmental level. This means that beyond a statement that a stressed syllable is maximally trimoraic, no moraic template for stressed syllables can be defined for Old Norse. However, there is a minimum word size that must be taken into consideration. Even if an open CV-syllable may occur as stressed in a disyllabic word, no content words with that shape exist in the language. A word that consists of only an open syllable invariably has a long vowel, and is therefore bimoraic. On the other hand, CVC-words may be monomoraic. The minimal word in $\mathrm{ON}$ is in other words a monomoraic $\mathrm{CV}_{\mu}(\mathrm{C})$ word, while a bare $\mathrm{CV}_{\mu}$-structure is excluded. ${ }^{5}$ The arguments in favour of this analysis, which is at odds with other analyses of the Old Germanic so-called short monosyllabic words in the literature, will be presented in section 1.2.1.

\subsection{Modern East Norwegian varieties}

Within East Norwegian there are three areas where light stressed syllables have been preserved. The two northern varieties, North and Mid Gudbrandsdal, are shown on the map inserted as Fig. 3 on page $\mathrm{X}$ below.

A more southern variety, Upper East Telemark, is in all aspects relevant to the topic of this paper equivalent with Mid Gudbrandsdal (Skulerud 1918, 1922), and will accordingly not be analysed as a separate type here. These dialects can be dubbed Pre-Prokosch dialects on account of the fact that light, stressed syllables have been preserved. In all other East Norwegian dialects, Urban East Norwegian included, Prokosch's law has been implemented.

The three types can be ranked as in (1) according to the degree to which light stressed syllables have been preserved.

a. Light root syllables have survived in monosyllabic as well as disyllabic words:

\section{i. North Gudbrandsdal (NGbr)}

b. Light root syllables have survived in disyllabic words only ${ }^{6}$ :

i. Mid Gudbrandsdal (MGbr) and Upper East Telemark

\footnotetext{
${ }^{4}$ In what follows, the tables showing the relevant data for the different varieties will be arranged in the same way, in order to facilitate comparison.

${ }^{5}$ One of the referees suggests that the lack of bare CV words should be captured by means of branchingness. Since I argue that the final C is extrametrical, this is not an option in the present case. See footnote 19 for further discussion.

${ }^{6}$ The stress pattern in disyllabic words with preserved light root syllables is often referred to as 'level' in the literature (see Kristoffersen 2007, 2008 and references cited there). It may therefore appear controversial to list this type as having stress on the initial syllable. But in the two works referred to I argue that the ambiguous stress percept stems from tonal, not metrical properties of these words. I shall base the present analysis on this assumption and hence with respect to metrical structure analyse $\mathrm{CV}_{\mu} . \mathrm{CV}_{\mu}$ words as canonical moraic trochees.
} 
Table 1 Old Norse-Structural options for root syllable in monosyllabic and disyllabic words

\begin{tabular}{|c|c|}
\hline Structure & Examples \\
\hline \multicolumn{2}{|c|}{ Monosyllabic words } \\
\hline $\mathrm{CV}_{\mu}$ & (Does not exist.) \\
\hline \multirow[t]{2}{*}{$\mathrm{CV}_{\mu} \mathrm{C}$} & /skin/, skin 'shine' (NoM. SG.) \\
\hline & /xlið/, hlið 'opening in fence' (NoM. SG.) \\
\hline \multirow{2}{*}{$\mathrm{CV}_{\mu \mu}(\mathrm{C})$} & /bru:/, brú 'bridge' (NOM. SG.) \\
\hline & /fi:n/, fin 'fine' (ADJ.) \\
\hline $\mathrm{CV}_{\mu} \mathrm{C}_{\mu}$ & /skinn/, skinn 'skin’ (NoM. SG.) \\
\hline $\mathrm{CV}_{\mu \mu} \mathrm{C}_{\mu}$ & /na:tt/, nátt 'night' (NoM. SG.) \\
\hline \multicolumn{2}{|c|}{ Disyllabic words } \\
\hline $\mathrm{CV}_{\mu} \cdot \mathrm{CV}_{\mu}$ & /'ba.ka/, baka 'to bake' (INFINITIVE) \\
\hline $\mathrm{CV}_{\mu \mu} \cdot \mathrm{CV}_{\mu}$ & /'vi:.sa/, vísa 'song' (NoM. SG.) \\
\hline $\mathrm{CV}_{\mu} \mathrm{C}_{\mu} \cdot \mathrm{CV}_{\mu}$ & /'skin.ni/, skinni ‘skin’ (DAT. SG.) \\
\hline $\mathrm{CV}_{\mu \mu} \mathrm{C}_{\mu} \cdot \mathrm{CV}_{\mu}$ & ${ }^{1}$ na:t.ta/, nátta 'the night' (GENITIVE. PL.) \\
\hline
\end{tabular}

c. All stressed syllables are heavy (Post-Prokosch dialects):

i. All other East Norwegian dialects

\subsubsection{North Gudbrandsdal}

Table 2 gives the structural options for the most conservative dialect type, North Gudbrandsdal (henceforth NGbr). ${ }^{7,8}$ One change with respect to $\mathrm{ON}$ is the elimination of the trimoraic type. As can be seen from the examples in Table 2, these have shortened and merged with the $\mathrm{CV}_{\mu} \mathrm{C}_{\mu}$ class. The monomoraic $\mathrm{CV}_{\mu} \mathrm{C}$ type has on the other hand survived, and in addition content words of a bare $\mathrm{CV}_{\mu}$ shape have developed.

We now return to the arguments in favour of analysing the $\mathrm{CV}_{\mu} \mathrm{C}$ type as monomoraic, in Old Norse as well as in NGbr. As noted above, the status of this contrast is somewhat controversial. Riad (1992: $240 \mathrm{ff}$.) claims that all monosyllabic words in $\mathrm{ON}$ are heavy, and that the final consonant in /skin/ accordingly must be moraic. Page (2001) writes of the same type that "[ $t]$ he monosyllables in which the lengthenings take place are already bimoraic", and proposes that vowel lengthening in monosyllables consisting of a short vowel followed by a short consonant must be due to what he calls "reanalysis of moraic consonants" (p. 247). Finally, Kiparsky (2008) in his analysis of Fenno-Swedish quantity derives a bimoraic winner from a CVC input by ranking FOOT-BINARITY above CONSONANT-EXTRAMETRICALITY with respect to dialects where "/CVC/ words remain unlengthened".

\footnotetext{
${ }^{7}$ The most important sources on NGbr are Horne (1917), Skulerud (1920), Ekre (1960), and Dagsgard (2006).

${ }^{8}$ In this and the tables to follow, words that have changed category with respect to the previous system are bolded.
} 


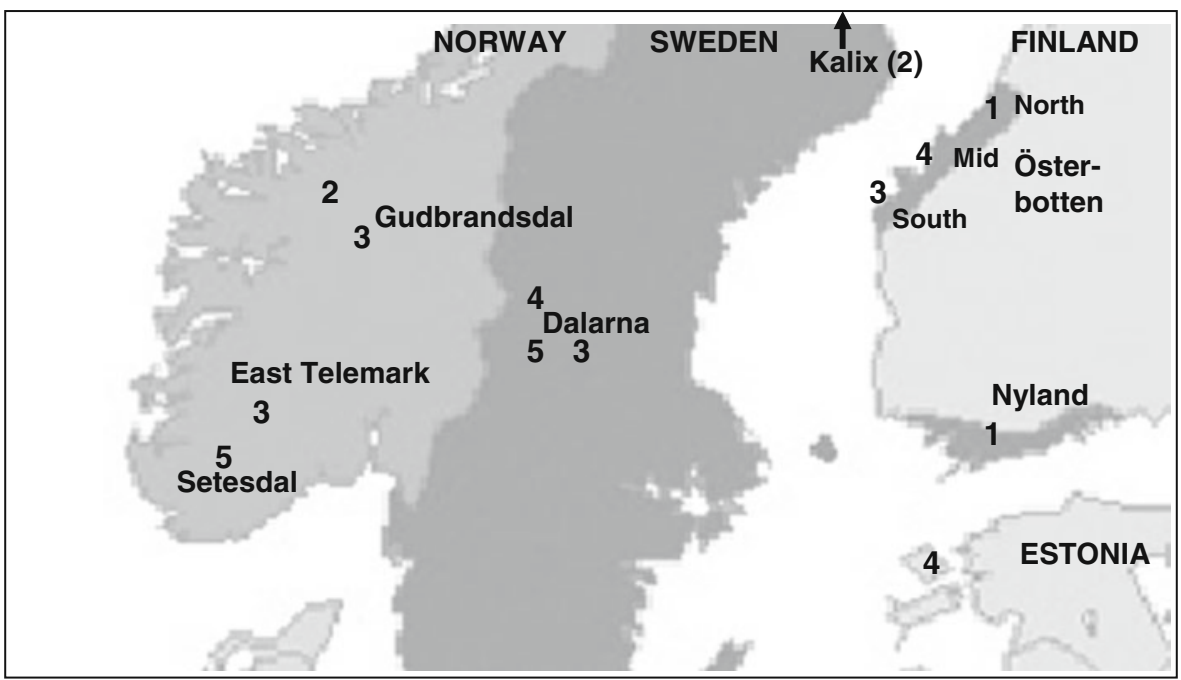

Fig. 3 Geographical distribution of grammars where Prokosch's law has not been fully implemented. Numbers refer to type according to the list given in (9) above

Table 2 NGbr-Structural options for root syllable in monosyllabic and disyllabic words

Structure $\quad$ Examples

Monosyllabic words

\begin{tabular}{|c|c|}
\hline $\mathrm{CV}_{\mu}$ & /le/, le 'opening in fence' (NoM. SG.) from ON /xlið/ \\
\hline $\mathrm{CV}_{\mu} \mathrm{C}$ & /sen/, skin 'shine' (Nom. SG.) \\
\hline \multirow[t]{2}{*}{$\mathrm{CV}_{\mu \mu}(\mathrm{C})$} & /bru:/, bru 'bridge' (NoM. SG.) \\
\hline & /fi:n/, fin 'fine' (ADJ.) \\
\hline \multirow[t]{2}{*}{$\mathrm{CV}_{\mu} \mathrm{C}_{\mu}$} & /sinn/, skinn 'skin’ (NoM. SG.) \\
\hline & /natt/, natt 'night' (NoM. SG.) \\
\hline $\mathrm{CV}_{\mu \mu} \mathrm{C}_{\mu}$ & Does not exist anymore \\
\hline \multicolumn{2}{|c|}{ Disyllabic words ${ }^{\mathrm{a}}$} \\
\hline $\mathrm{CV}_{\mu} \cdot \mathrm{CV}_{\mu}$ & Pbo.ko/, baka 'to bake' (INFINITIVE) $^{\text {b }}$ \\
\hline $\mathrm{CV}_{\mu \mu} \cdot \mathrm{CV}_{\mu}$ & Pºi:.se/, vise 'song' (Nom. SG.) \\
\hline \multirow[t]{2}{*}{$\mathrm{CV}_{\mu} \mathrm{C}_{\mu} \cdot \mathrm{CV}_{\mu}$} & /1sin.nə/ skinnet 'the skin' (DEF. SG.) \\
\hline & /1nat.ta/, natta 'the night' (DEF. SG.) \\
\hline $\mathrm{CV}_{\mu \mu} \mathrm{C}_{\mu} \cdot \mathrm{CV}_{\mu}$ & Does not exist anymore \\
\hline
\end{tabular}

${ }^{a}$ The superscripted numerals denote tonal accent 1 or 2 . Monosyllabic words have accent 1 by default (Kristoffersen 2006).

${ }^{\mathrm{b}}$ The forms $/ 2$ bo.ko/ vs. $/ 2$ vi:se/ in Table 2, which both ended in /-a/ in ON, exemplify so-called 'vowel balance' (Riad 1992; Kristoffersen 2007, 2008), whereby vowels in unstressed syllables after a heavy root syllable reduce, whereas they are preserved as full vowels after light root syllables. Vowel balance characterizes all East Norwegian dialects. Even if it is clearly related to prosodic structure, it is orthogonal to the topic of the present paper. 
Contra these analyses I contend that the type traditionally described as consisting of short vowel followed by a short consonant was monomoraic in Old Norse, and remains so in the NGbr dialect. The main synchronic argument in favour of the final consonant being extrametrical and therefore non-moraic is the fact that if a vowel-initial suffix is added to a stem of this type, the consonant exclusively syllabifies as onset of the added syllable. The disyllabic def.sg. form of /sen/, skin 'shine', morphologically /sen-e/, is realized as [ ${ }^{1} \mathrm{~s} . \mathrm{n}$ ə]. This contrasts with the bimoraic CVC-type, exemplified in the table by the noun skinn 'skin'. Here the def.sg. is realized with a geminate, [ ${ }^{1}$ sin.nə], where the consonant serves both as bearer of the second mora of the stressed syllable and as onset of the final syllable.

This analysis is supported by the fact that there is a clear difference with respect to duration between moraic and non-moraic final consonants in NGbr. Data published in Kristoffersen (1990: 189f.) show that the final consonant of a $\mathrm{CV}_{\mu} \mathrm{C}$ word has a duration that is about half of the moraic consonant in a $\mathrm{CV}_{\mu} \mathrm{C}_{\mu}$ word (80 vs. $170 \mathrm{~ms}$ ). This can be compared with the mean duration of a post-moraic consonant in a $\mathrm{CV}_{\mu \mu} \mathrm{C}$ word, which is $90 \mathrm{~ms}$, that is, about the same as the consonant that I claim is postmoraic and extrametrical in $\mathrm{CV}_{\mu} \mathrm{C}$ words. ${ }^{9}$

While these data from NGbr do not by themselves prove that Old Norse had the same system, they make it seem likely. In my opinion, the fact that there also in ON existed a contrast between CVC words with short and long final consonants, $\mathrm{cf}$. the difference between /skin/ and /skinn/, is a stronger argument in favour of the first type being monomoraic than is the lack of bare $\mathrm{CV}_{\mu}$ words, which we would expect if the language allowed monomoraic $\mathrm{CV}_{\mu} \mathrm{C}$ words. The fact that $\mathrm{NGbr}$ has developed exactly this type is of course another argument in favour of the analysis proposed here.

The changes that have taken place compared to ON, both marked by boldface in Table 2, are summarized under (2).

(2)

a. Development of content words with a bare $\mathrm{CV}_{\mu}$-shape.

b. Elimination of the superheavy type, both in monosyllabic and disyllabic words.

The majority of the $\mathrm{CV}_{\mu}$-words have developed from $\mathrm{ON} \mathrm{CV}_{\mu} \mathrm{C}$-words ending in $/ ð /$, such as the example given in Table 2. In this type, /ð/ has deleted without subsequent compensatory lengthening, which we might have expected if the final consonant were moraic. ${ }^{10}$

\subsubsection{Mid Gudbrandsdal}

Table 3 gives the structural options for Mid Gudbrandsdal (henceforth MGbr), a region located immediately to the south of NGbr. ${ }^{11}$ We see that the main difference with respect to $\mathrm{NGbr}$ is that the short, monosyllabic $\mathrm{CV}_{\mu} \mathrm{C}$-type has been eliminated, its ON members having been expanded into heavy syllables either by vowel lengthening (/le:/) or by moraification of the postvocalic consonant (/senn/). Light stressed syllables have been preserved in the disyllabic type, however; here the

\footnotetext{
${ }^{9} N=12$ for each category, with three tokens of each type produced by four speakers of the NGbr dialect.

${ }^{10}$ According to the list in Dagsgard (2006: $161 \mathrm{ff}$.), this class comprises about 20 words.

11 The information on MGbr has been culled from Fliflet (1954).
} 
Table 3 MGbr-Structural options for root syllable in monosyllabic and disyllabic words

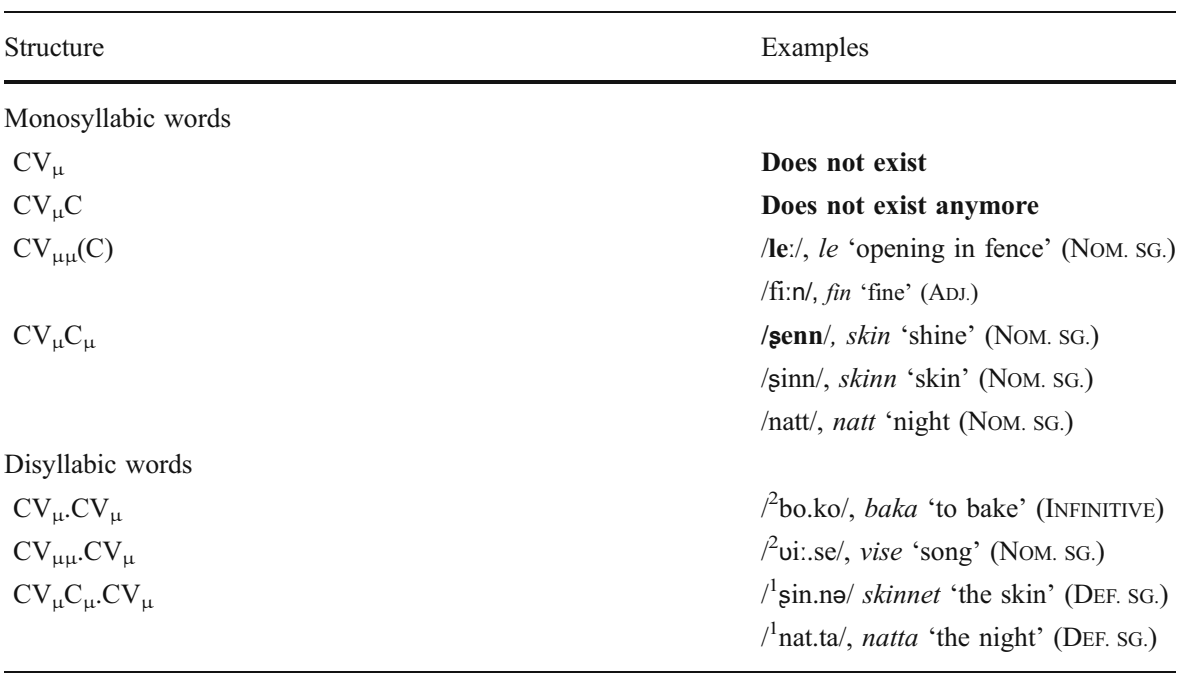

system is the same as in NGbr and ON. And as in NGbr, the superheavy type has been eliminated.

\subsubsection{Urban East Norwegian}

We finally turn to the Post-Prokosch varieties, represented by Urban East Norwegian. Table 4 shows that in addition to the changes found in NGbr and MGbr, we here find vowel lengthening in the root syllable of the disyllabic ON $\mathrm{CV}_{\mu} \mathrm{CV}_{\mu}$ class. The result is full implementation of Prokosch's law: All stressed syllables must be precisely bimoraic. ${ }^{12}$

\subsubsection{Summary}

Table 5 is a summary of the dialect differences presented in the preceding sections. The dialects are ordered by complexity, with ON and NGbr on top, and PostProkosch Urban East Norwegian at the bottom.

\section{Theory}

Before we proceed with the analysis of these differences, we must establish the theoretical underpinnings of the analysis. I assume that the reader has a basic knowledge of Optimality Theory (Kager 1999; McCarthy 2002; Prince and Smolensky 2004 [1993]), and will concentrate here on two aspects of the theory

\footnotetext{
${ }^{12}$ In addition we see that the traces of vowel balance have disappeared. This is a feature of the urban varieties of East Norwegian. In rural dialects, the pattern has survived, despite the fact that the conditioning factor, the difference between light and heavy root syllable, has now completely disappeared, from urban and (most) rural varieties alike.
} 
Table 4 Urban East Norwegian-Structural options for root syllable in monosyllabic and disyllabic words

Structure

Examples

Monosyllabic words

$\mathrm{CV}_{\mu \mu}(\mathrm{C})$

${ }^{1} \mathrm{le}: /$, le 'opening in fence' (Nom. SG.)

$\mathrm{CV}_{\mu} \mathrm{C}_{\mu}$ /fi:n/, fin 'fine' (ADJ.)

/'sinn/, skinn 'skin, shine' (NOM. SG.)

$/{ }^{1}$ natt/, natt 'night (NoM. SG.)

Disyllabic words

$\mathrm{CV}_{\mu} \cdot \mathrm{CV}_{\mu}$

$\mathrm{CV}_{\mu \mu} \cdot \mathrm{CV}_{\mu}$

Does not exist anymore

/2ba:.ke/, baka 'to bake' (INFINITIVE)

prui..se/, vise 'song' (Nom. SG.)

$\mathrm{CV}_{\mu} \mathrm{C}_{\mu} \cdot \mathrm{CV}_{\mu}$

$/{ }^{1}$ sin.nə/ skinnet 'the skin' (DEF. SG.)

/'nat.ta/, natta 'the night' (DEF. SG.)

that I see as most relevant in the present context. These are the Richness of the Base hypothesis and the hypothesis that the theory will render typological predictions through so-called factorial typologies.

The Richness of the Base hypothesis (McCarthy 2002: 70f.; Prince and Smolensky 2004 [1993]: 225) puts the whole burden of selecting the optimal output candidate for a given input on CoN, i.e., the set of ranked constraints that make up the active part of a given grammar. This means that any input whose structural makeup is not in accordance with what is a well-formed output in the language, will surface as modified so that it complies with these well-formedness conditions. For example, if a $\mathrm{CV}_{\mu} \cdot \mathrm{CV}_{\mu}$ input is submitted to the grammar holding for Urban East Norwegian, which does not tolerate light, stressed syllables, the fully faithful candidate will be eliminated by a high-ranking markedness constraint banning such syllables. A less faithful candidate that respects this markedness constraint will

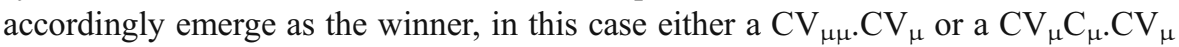
output. The hypothesis that the burden of selecting the correct output rests wholly on CON in other words means that we are not allowed to ban certain input types from analysis because they are not attested as well-formed outputs.

Table 5 Summary of dialect differences with respect to structural options for root syllable in monosyllabic and disyllabic words

\begin{tabular}{|c|c|c|c|c|c|c|}
\hline & \multicolumn{3}{|l|}{ Light } & \multicolumn{2}{|c|}{ Heavy } & \multirow{2}{*}{$\begin{array}{l}\text { Trimoraic } \\
\mathrm{CV}_{\mu \mu} \mathrm{C}_{\mu}\end{array}$} \\
\hline & $\mathrm{CV}_{\mu}$ & $\mathrm{CV}_{\mu} \mathrm{C}$ & $\mathrm{CV}_{\mu} \cdot \mathrm{CV}_{\mu}$ & $\mathrm{CV}_{\mu \mu}$ & $\mathrm{CV}_{\mu} \mathrm{C}_{\mu}$ & \\
\hline Old Norse & & $\sqrt{ }$ & $\sqrt{ }$ & $\sqrt{ }$ & $\sqrt{ }$ & $\sqrt{ }$ \\
\hline North Gudbrandsdal & $\sqrt{ }$ & $\sqrt{ }$ & $\sqrt{ }$ & $\sqrt{ }$ & $\sqrt{ }$ & \\
\hline Mid Gudbrandsdal & & & $\sqrt{ }$ & $\sqrt{ }$ & $\sqrt{ }$ & \\
\hline Urban East Norwegian & & & & $\sqrt{ }$ & $\sqrt{ }$ & \\
\hline
\end{tabular}


The implication of this is that all the prosodic types that are specified in the left-hand column of Tables 1, 2, 3 and 4 above are possible and legitimate inputs in the grammars of all the dialects under discussion, irrespective of whether they represent well-formed output types or not. To the degree that they do not, it is the task of the ranked constraints to eliminate them and select a more well-formed albeit less faithful candidate in its place. From a diachronic point of view, this renders the hypothesis that the transition from one state in the historical development outlined in section 1 to another can be modelled as reranking of at least two constraints with respect to each other within the same constraint hierarchy. The range of possible inputs will by the Richness of the Base hypothesis remain the same across all grammars; the constraint ranking will in all cases decide which of them emerges as winner in a given variety.

We now turn to factorial typologies. According to McCarthy (2002: 12), "[e]very permutation of the constraints in CON is predicted to be a possible human language, and the grammar of every observed human language must be one of those permutations". Abstracting away from the (possible) existence of universal ranking relationships, this means that an exhaustive set of rankings of a set of interacting constraints, a so-called factorial typology, will represent a hypothesis about the range of variation we should find within the specific sub-domain of the grammar that is defined by these constraints. Since diachronic change is a transition from one possible grammar to another, change must also be delimited by factorial typologies, in the sense that a given factorial typology by hypothesis will determine what changes are possible with respect to the same set of constraints. A set of dialects such as those summarized in Table 5 should by this hypothesis be subject to an analysis limited to different permutations of the same set of constraints, although the possibility of interference of additional constraints cannot of course be excluded a priori.

The implications for the present analysis of these two principles, the Richness of the Base and the Factorial Typology Principle, should now be clear. The grammars we shall develop for each of the varieties listed in Table 5 must be able to tackle the same range of input types; it is the task of the constraints to select the correct output in each case. And since we are dealing with closely related grammars, both diachronically and typologically, and the same phenomenon, viz. syllable quantity expressed by the number of moras a stressed syllable may consist of, our null hypothesis will be that the set of active constraints can be held stable through all the grammars. The dialect differences will in other words, and according to the principle of factorial typologies, by hypothesis emerge as different rankings within the same constraint set.

A primary goal of the analysis that follows is therefore to test to what extent this can be shown to hold when we at the same time restrict ourselves to employing constraints that have already proven to be useful and well motivated in analyses of other languages. To the extent that we succeed in this, we have established strong arguments in favour of the constraint set assumed being the correct one.

\section{The constraint set}

The grammar shown under (3) is a minimally modified version of the grammar of East Norwegian developed by Rice (2006). The definitions in the right-hand column are taken from Rice, except that those defining the two faithfulness constraints have 
been refined in accordance with a suggestion made by one of the referees. Even if Rice's grammar also accounts for stress placement, which is outside the scope of the present article, I shall use his analysis as a starting point, both with respect to ranking and with respect to the set of relevant constraints needed in the analysis.

\section{(3) Urban East Norwegian grammar}

\begin{tabular}{|c|c|}
\hline STRESS-TO-WEIGHT (SW): & A stressed syllable must not be monomoraic, \\
\hline FOOTBINARITY (FB): & A foot is binary at the level of the syllable or the mora. \\
\hline \multicolumn{2}{|l|}{$\gg$} \\
\hline $\operatorname{MAXLINK}_{\mu}[\mathrm{SEG}]^{13}:$ & $\begin{array}{l}\text { For two corresponding segments, if S1 (in the input) is associated to } \\
\text { some mora, then S2 (in the output) is associated to the same mora. }\end{array}$ \\
\hline DEPLINK- $_{\mu}[\mathrm{SEG}]:$ & $\begin{array}{l}\text { For two corresponding segments, if } \mathrm{S} 1 \text { (in the output) is associated to } \\
\text { some mora, then S2 (in the input) is associated to the same mora. }\end{array}$ \\
\hline \multicolumn{2}{|l|}{$>>$} \\
\hline NONFinality: & The prosodic head of the word does not fall on the word-final syllable, \\
\hline NoCoDA: & A syllable does not have a coda. \\
\hline \multicolumn{2}{|l|}{$>>$} \\
\hline AlignRight: & $\begin{array}{l}\text { For every head of a prosodic word (syllable bearing main stress), there } \\
\text { is a prosodic word such that the right edge of the head of the prosodic } \\
\text { word coincides with the right edge of the prosodic word. }\end{array}$ \\
\hline
\end{tabular}

The grammar shown in (3) deviates from the Rice (2006) grammar in that DEPLINK $_{\mu}$ is not part of Rice's grammar. The reason for including this constraint is, as will become clear in subsequent sections, that DEPLINK $\mu$, ranked above STRESSTO-WEIGHT, is necessary for accounting for dialects where light stressed syllables have been preserved. With this ranking, mora epenthesis in order to satisfy STRESSTO-WEIGHT will be blocked by the higher ranking DEP constraint, and a light, stressed syllable in the input will survive. ${ }^{14}$

STRESS-TO-WEIGHT and FoOtBinARity are the markedness constraints that respectively force a stressed syllable to be heavy and the stress foot to surface as a moraic trochee, either in the shape of one heavy syllable or two light ones with initial stress. The two faithfulness constraints, DePLINK $\mu$ and MAXLINK $_{\mu}$, which focus on the presence vs. absence of moraic links instead of the presence vs. absence of moras proper, have been taken from Morén $(2000,2001)$. When these are lower

\footnotetext{
${ }^{13}$ For simplicity of exposition, this and the following DePLiNK- $\mu$ [SEG] constraint will be abbreviated as MAXLink $\mu$ and DePLink $\mu$ respectively.

14 At the same time, Rice's constraint WEIGHT-TO-STRESS has been eliminated from the constraint set. In Rice's analysis mora insertion comes for free, as long as it does not lead to violations of WEIGHT-TO-STRESS by creating more than one heavy syllable eligible for stress assignment where only one may carry stress in the output. In this way, mora insertion is checked by WEIGHT-TO-STRESS in Rice's analysis. But without a DEP constraint, Rice's grammar cannot account for the full range of dialect variation addressed in the present paper. The revised grammar under (3) is all the same equivalent to Rice's grammar. It has been checked against all input forms evaluated in Rice (2006), and in all cases the results are identical.
} 
ranked than StRESS-TO-WEIGHT and FoOtBINARITY, insertion and deletion of moras can take place in order to satisfy the higher ranked markedness constraints. With the ranking reversed, that is, when $\operatorname{DEPLINK}_{\mu}$ and $\mathrm{MAXLINK}_{\mu}$ are ranked above the two markedness constraints, the winning candidate will be faithful to the input irrespective of the number of moras present in the stressable syllable in the input.

NoCoDA is included in the analysis in order to choose a winner in cases where a candidate with a long vowel competes with a candidate where weight is encoded by gemination. Finally, NonFinAlity and AlignRight are both constraints that primarily address stress placement in longer words. They are therefore somewhat orthogonal to the subject of the present paper, but they have been included in order to facilitate a comparison between Rice (2006) and the alternative analysis of PostProkosch Norwegian presented here. Both, however, will be excluded from the main analysis that follows below, in order to keep the central concern of the paper, the tension between the two markedness constraints and the two faithfulness constraints, in focus.

With respect to NonFinality, this means that certain candidates violating the constraint will be excluded from the candidate sets to be evaluated in the main sections. Recall that postmoraic consonants in monosyllabic words in accordance with Rice's analysis were assumed to be extrametrical in section 1 above. A word with a long vowel followed by a single consonant was consequently represented as $\mathrm{CV}_{\mu \mu}(\mathrm{C})$, where the parenthesis denotes extrametricality. (An alternative representation is $\mathrm{CV}_{\mu \mu}$.C, where the dot denotes a syllable boundary and $\mathrm{C}$ the onset of an empty syllable.) Any candidate with a final $\mathrm{C}$ that in this way constitutes a defective syllable will satisfy NonFinALITY, while a candidate where the $\mathrm{C}$ is included in the preceding syllable as a coda, as in $\mathrm{CV}_{\mu \mu} \mathrm{C}$, will not. It is the latter candidate type that is excluded from candidate sets in order to focus the analysis. These candidates, along with the constraints, are part of the fuller analyses available with the electronic version of this article (see below).

\section{Analysis}

In addition to a sufficient number of constraints, exhaustive optimality theoretic analyses often imply large set of tableaux evaluating different input types and for each input type a substantial number of candidates. To the extent that such tableaux are included in the running text of a paper, they will reduce readability by both taking up too much space and by including aspects of the analysis that are not directly relevant to the problem under discussion. This potential problem has been solved in the following way in this paper: For each dialect, a full analysis is published in supplemental materials included online with the electronic version of this article. ${ }^{15}$ In the running text, only those parts of the analyses that are relevant to the problem at hand will be included, in most cases the crucial ranking arguments.

\footnotetext{
${ }^{15}$ This material is available on the website for The Journal of Comparative Germanic Linguistics: <http:// www.springerlink.com/content/102925/>.
} 
Note that even if I refer to the analyses posted at the website as "full", they are partial with respect to the analysis of UEN given in Rice (2006), since stress placement is not part of the present analysis. The candidate forms at the website are therefore restricted to monosyllabic and disyllabic input types, the latter type with a single intervocalic consonant, where stress in the latter is assumed to fall on the initial syllable. Within each of these, both input types and the candidate set vary systematically with respect to weight (mora count) and instantiation of weight by either vowel length or a moraic consonant.

\subsection{Urban East Norwegian}

We shall start with the best attested variety in the set to be analysed, modern PostProkosch Norwegian, and work our way backwards through the varieties presented in section 1 until we reach Old Norse. Urban East Norwegian (UEN) (Kristoffersen 2000 ) is the variety used by most speakers having grown up in urban settlements, including the capital Oslo, in the south-eastern part of Norway. It is also the variety usually referred to as 'Norwegian' or 'Standard Norwegian' in linguistic surveys and analyses such as Maddieson (1984) and Ladefoged and Maddieson (1996). ${ }^{16}$

The basic grammar is given under (4). Note that it includes all the constraints introduced in section 3, even if NonFinALITY and ALIGNRight are excluded from the tableaux that follow below. The reason for including them is that they are part of the fuller analyses presented at the companion website. Note also that the grammar includes fewer ranking relationships than the grammar given under (3) above. I shall return to this point in a moment.

(4) UEN Grammar

\section{FootBinarity (FB), Stress-to-Weight (SW) $>$ DepLink $_{\mu}$, MaxLink $_{\mu}$, NonFinality (NF), NoCoda $>>$ AlignRight}

The fact that all stressed syllables must be precisely bimoraic implies that STRESS-TOWEIGHT and FOOTBINARITY must dominate the two faithfulness constraints, as assumed in (4). This ranking will fatally penalize monomoraic and trimoraic syllables in the input.

Given the fact that inputs with bimoraic stressed syllables already satisfy the two topranked constraints, the winning candidate will not be subject to any alterations enforced

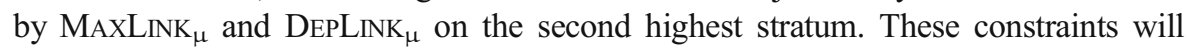
only be relevant for inputs which contain too many or too few moras with respect to the requirements defined by the two top-ranked markedness constraints. The analysis below will therefore concentrate on these types, while the reader is referred to the companion website for the full analysis including bimoraic input types.

Before we proceed with the analysis, we need to establish the argument for ranking NoCODA below the markedness constraints in all grammars. Tableau 1 shows that if NoCODA is ranked above the two faithfulness constraints, it will result

$\overline{16}$ These are usually based on Vanvik $(1972,1973)$. 
in an incorrect winner with respect to $\mathrm{a}_{\mu} \mathrm{C}_{\mu}$ input. ${ }^{17}$ The reason is that a candidate with a long vowel will always emerge as winner, contrary to the fact that words with $\mathrm{CV}_{\mu} \mathrm{C}_{\mu}$ structure abound in the language. NoCODA therefore cannot be ranked above the faithfulness constraints.

Tableau 1: Evidence for ranking NoCoDA below faithfulness

\begin{tabular}{|c||c:c|c|c|c|}
\hline $\mathrm{CV}_{\mu} \mathrm{C}_{\mu}$ & $\mathrm{SW}$ & $\mathrm{FB}$ & NoCODA & DEPLINK $_{\mu}$ & MAXLINK $_{\mu}$ \\
\hline \hline $\mathrm{a})\left(\mathrm{si}_{\mu} \mathrm{n}_{\mu}\right) \mathrm{n}$ & & & $* !$ & & \\
\hline b) $\left(\mathrm{si}_{\mu \mu}\right) \mathrm{n}$ & & & & $*$ & $*$ \\
\hline
\end{tabular}

Since there appear to be no arguments for ranking NoCODA below faithfulness when the set of input is restricted to mono- and disyllabic forms, I assume that the three constraints belong to the same stratum. In other words, I disregard the ranking relationship established within the fuller analysis of Rice (2006), reflected in the grammar given under (3) above, since it cannot be established within the more restricted data set analysed here. This will hold for several other potential rankings in the analyses that follow. Only where specific rankings can be established by means of the candidate sets included in the analysis, will constraints be ranked with respect to each other. In all other cases they will be assumed to belong to the same stratum, also in cases where inclusion of candidates displaying different stress placement options would have established a ranking between them.

We now proceed to the input types that do not conform to the output requirements with respect to mora count. We start with monosyllabic inputs, and restrict the analysis to the sub-minimal $\mathrm{CV}_{\mu} \mathrm{C}$ type. Tableau 2 shows that the two top-ranked markedness constraints, STRESS-TO-WEIGHT and FootBinARITY, enforce a bimoraic output irrespective of mora count in the input, in accordance with the inviolable requirement that stressed syllables be precisely bimoraic in UEN. Tableau 3 shows the effect of ranking faithfulness above the two markedness constraints. Now the most faithful candidate wins, in violation of the observed ban on monomoraic stressed syllables in UEN.

The full evaluations at the companion website will show that the grammar in all cases returns bimoraic well-formed outputs, $\mathrm{CV}_{\mu \mu} \mathrm{C}$ from superheavy $\mathrm{CV}_{\mu \mu} \mathrm{C}_{\mu}$, $\mathrm{CV}_{\mu \mu} \mathrm{C}$ from light $\mathrm{CV}_{\mu} \mathrm{C}$, and $\mathrm{CV}_{\mu \mu}$ from $\mathrm{CV}_{\mu}$. However, in some cases the actual outputs are not the same as the attested forms in East Norwegian, which are those marked by a sad face in Tableau 2. While the attested output of the moraic expansion of monosyllabic $\mathrm{CV}_{\mu} \mathrm{C}$ words in East Norwegian in most cases are words characterized by a short vowel and moraic consonant (candidate b), the grammar, due to NoCoDA, returns the $\mathrm{CV}_{\mu \mu} \mathrm{C}$ (candidate c) as winner. And while the attested

\footnotetext{
${ }^{17}$ Recall from section 3 that in the tableaux in the main text all candidates generated from consonant final inputs have been supplied with an extrametrical $\mathrm{C}$ in order to eliminate NonFINALITY from the analysis. See again the companion website for the full analysis.
} 
output of the shortening of trimoraic syllables is $\mathrm{CV}_{\mu} \mathrm{C}_{\mu}$ in all East Norwegian varieties, the grammar again returns $\mathrm{CV}_{\mu \mu} \mathrm{C}$ as winner due to the influence of NoCoDA, cf. Tableau 4 below. $^{18}$

Tableau 2: UEN_Monosyllabic input: Markedness ranked above faithfulness

\begin{tabular}{|c|c|c|c|c|c|c|}
\hline & $\mathrm{CV}_{\mu} \mathrm{C}$ & SW & FB & $\operatorname{DEPLINK}_{\mu}$ & MAXLINK $_{\mu}$ & NoCODA \\
\hline & a) $\left(\mathrm{si}_{\mu}\right) \mathrm{n}$ & $* !$ & $*$ & & & \\
\hline$\ddot{\theta}$ & b) $\left(s \mathrm{i}_{\mu} \mathrm{n}_{\mu}\right) \mathrm{n}$ & & & * & & *! \\
\hline$s$ & c) $\left(s i_{\mu \mu}\right) n$ & & & $*$ & & \\
\hline & d) $\left(\mathrm{si}_{\mu \mu} \mathrm{n}_{\mu}\right) \mathrm{n}$ & & $* !$ & $* *$ & & * \\
\hline
\end{tabular}

Tableau 3: UEN-Monosyllabic input: Faithfulness ranked above markedness

\begin{tabular}{|c|c|c|c|c|c|}
\hline $\mathrm{CV}_{\mu} \mathrm{C}$ & DEPLINK $_{\mu}$ & $\mathrm{MAXLINK}_{\mu}$ & SW & FB & NoCODA \\
\hline$\sigma^{*}$ a) $\left(s i_{\mu}\right) n$ & & & $*$ & $*$ & \\
\hline b) $\left(s i_{\mu} n_{\mu}\right) n$ & $* !$ & & & & * \\
\hline c) $\left(s i_{\mu \mu}\right) n$ & *! & & & & \\
\hline d) $\left(s i_{\mu \mu} n_{\mu}\right) n$ & $* ! *$ & & & $*$ & * \\
\hline
\end{tabular}

Tableaux 4 and 5 show that the modified grammar renders the same results with respect to disyllabic inputs, here exemplified by the trimoraic input type, as well as the same problems with respect to the attested development of formerly trimoraic syllables. We see again that when the two markedness constraints are top-ranked, the winner is pared down to bimoraic, while the opposite ranking in Tableau 5 returns the maximally faithful trimoraic candidate as winner, in violation of the observed ban on this type in UEN.

\footnotetext{
${ }_{18}$ A full analysis of this problem, which is somewhat orthogonal to the topic of the present paper, must be left to future research. Since corresponding words turn up with long vowels in other dialects, and similar variation can be observed with respect to disyllabic words with former monomoraic and trimoraic stress, this topic deserves a typological analysis on its own. (For important contributions to such an analysis, see, e.g., Hesselman 1902 and Riad 1992.) I shall therefore restrict myself to pointing out the mismatches in the tableaux that follow by means of a sad face, without further comment.
} 
Tableau 4: UEN_Disyllabic input: Markedness ranked above faithfulness

\begin{tabular}{|c|c|c|c|c|c|c|}
\hline & $\mathrm{CV}_{\mu \mu} \mathrm{C}_{\mu} \mathrm{V}_{\mu}$ & SW & FB & $\operatorname{DEPLINK}_{\mu}$ & MAXLINK $_{\mu}$ & NoCODA \\
\hline & a) $\left(\right.$ ná $\left._{\mu} \cdot \mathrm{ta}_{\mu}\right)$ & *! & & & $* *$ & \\
\hline$\ddot{\theta}$ & b) $\left(n a_{\mu} t_{\mu}\right) t a_{\mu}$ & & & & $*$ & $* !$ \\
\hline$\infty$ & c) $\left(\right.$ ná $\left._{\mu \mu}\right) t a_{\mu}$ & & & & * & \\
\hline & d) $\left(\right.$ ná $\left._{\mu \mu} \mathrm{t}_{\mu}\right) \mathrm{ta}_{\mu}$ & & $* !$ & & & * \\
\hline
\end{tabular}

Tableau 5: UEN_Disyllabic input: Faithfulness ranked above markedness

\begin{tabular}{|c||c|c|c|c|c|}
\hline $\mathrm{CV}_{\mu \mu} \mathrm{C}_{\mu} \mathrm{V}_{\mu}$ & DEPLINK $_{\mu}$ & MAXLINK $_{\mu}$ & $\mathrm{SW}$ & $\mathrm{FB}$ & NoCoDA \\
\hline \hline a) $\left(\mathrm{ná}_{\mu} \cdot \mathrm{ta}_{\mu}\right)$ & & $* ! *$ & $*$ & & \\
\hline b) $\left(\mathrm{ná}_{\mu} \mathrm{t}_{\mu}\right) \mathrm{ta}_{\mu}$ & & $* !$ & & & $*$ \\
\hline c) $\left(\mathrm{ná}_{\mu \mu}\right) \mathrm{ta}_{\mu}$ & & $* !$ & & & \\
\hline d) $\left(\mathrm{ná}_{\mu \mu} \mathrm{t}_{\mu}\right) \mathrm{ta}_{\mu}$ & & & & $*$ & $*$ \\
\hline
\end{tabular}

\subsection{Mid Gudbrandsdal (MGbr)}

We now proceed to the MGbr dialect. Recall from section 1 that the difference between MGbr and UEN is that disyllabic words may have a light stressed syllable, while monosyllabic words must be bimoraic. This means that the constraint STRESS-TOWEIGHT, which requires that stressed syllables be bimoraic, is violated by the winning candidate in the former case, and therefore it cannot be top-ranked in this dialect, as it is in UEN. On the other hand, both disyllables made up of two light syllables and monosyllables consisting of a heavy syllable are instantiations of the canonical moraic trochee (Hayes 1995: 69). Since only disyllabic words can have a light stressed syllable, while monosyllabic words are invariably bimoraic, FOOTBINARITY appears to be unviolated in MGbr. This means that moraic faithfulness by hypothesis should dominate STRESS-TO-WEIGHT but not FoOtBINARITY. But since superheavy syllables are banned, both faithfulness constraints cannot be top-ranked.

The grammar modified in accordance with this hypothesis is shown under (5). The only difference between the MGbr grammar and the UEN grammar under (3) above is that STRESS-TO-WEIGHT has been demoted to the position below the two faithfulness constraints.

(5) Grammar of Mid Gudbrandsdal

FootBinarity (FB) $>>$ DepLinK $_{\mu}$, MAXLink $_{\mu}>$ Stress-To-Weight (SW), NonFinality (NF), NoCoda $>>$ AlignRight

This ranking will cause disyllabic inputs with a light root syllable to emerge as winners without modification of their moraic structure, due to the high cost incurred 
by violations of DePLink ${ }_{\mu}$. This is shown in Tableau 6. That inputs with a superheavy root syllable, $\mathrm{CV}_{\mu \mu} \mathrm{C}_{\mu} \mathrm{V}_{\mu}$, also surface as bimoraic in MGbr, is shown in Tableau 7.

Tableau 6: $\mathrm{MGbr}$-Evaluation of $\mathrm{CV}_{\mu} \mathrm{CV}_{\mu}$ input

\begin{tabular}{|c||c|c|c|c|c|}
\hline $\mathrm{CV}_{\mu} \mathrm{CV}_{\mu}$ & $\mathrm{FB}$ & $\operatorname{DEPLINK}_{\mu}$ & $\mathrm{MAXLINK}_{\mu}$ & $\mathrm{SW}$ & NOCODA \\
\hline \hline a) $\left(\mathrm{bá}_{\mu} \cdot \mathrm{ka}_{\mu}\right)$ & & & & $*$ & \\
\hline b) $\left(\mathrm{bá}_{\mu} \mathrm{k}_{\mu}\right) \mathrm{ka}_{\mu}$ & & $* !$ & & & $*$ \\
\hline c) $\left(\mathrm{bá}_{\mu \mu}\right) \mathrm{ka}_{\mu}$ & & $* !$ & & & \\
\hline d) $\left(\mathrm{bá}_{\mu \mu} \mathrm{k}_{\mu}\right) \mathrm{ka}_{\mu}$ & $* !$ & $* *$ & & & $*$ \\
\hline
\end{tabular}

Tableau 7: MGbr-Evaluation of disyllabic, bimoraic and trimoraic inputs

\begin{tabular}{|c|c|c|c|c|c|c|}
\hline & $\mathrm{CV}_{\mu \mu} \mathrm{C}_{\mu} \mathrm{V}_{\mu}$ & FB & $\operatorname{DEPLINK}_{\mu}$ & MAXLINK $_{\mu}$ & SW & NoCODA \\
\hline & a) $\left(\right.$ ná $_{\mu} \cdot$ te $\left.e_{\mu}\right)$ & & & $* ! *$ & * & \\
\hline$\ddot{\theta}$ & b) $\left(\right.$ ná $\left._{\mu} \mathrm{t}_{\mu}\right) \mathrm{te} \mathrm{e}_{\mu}$ & & & $*$ & & $* !$ \\
\hline$s$ & c) $\left(\right.$ ná $\left._{\mu \mu}\right) t_{\mu}$ & & & $*$ & & \\
\hline & d) $\left(\right.$ ná $\left._{\mu \mu} \mathrm{t}_{\mu}\right) \mathrm{te} \mathrm{e}_{\mu}$ & $* !$ & & & & * \\
\hline
\end{tabular}

As can be seen from Tableau 8, the grammar crucially returns the correct, bimoraic input from a monomoraic, monosyllabic input. Since any monomoraic (as well as trimoraic) candidate will violate top-ranked FOOTBINARITY, only bimoraic winners are possible with respect to monosyllabic inputs in MGbr. The MGbr grammar, in other words, correctly derives the same set of winners as the UEN grammar with respect to monosyllabic inputs.

Tableau 8: MGbr-Evaluation of monosyllabic, monomoraic input

\begin{tabular}{|c|c|c|c|c|c|c|}
\hline & $\mathrm{CV}_{\mu} \mathrm{C}$ & FB & $\operatorname{DEPLINK}_{\mu}$ & MAXLINK $_{\mu}$ & SW & NoCODA \\
\hline & a) $\left(s k i_{\mu}\right) n$ & $* !$ & & & $*$ & \\
\hline 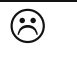 & b) $\left(\mathrm{ski}_{\mu} \mathrm{n}_{\mu}\right) \mathrm{n}$ & & $*$ & & & $* !$ \\
\hline$\infty$ & c) $\left(\mathrm{ski}_{\mu \mu} \cdot\right) \mathrm{n}$ & & $*$ & & & \\
\hline & d) $\left(\mathrm{ski}_{\mu \mu} \mathrm{n}_{\mu}\right) \mathrm{n}$ & $* !$ & $* *$ & & & $*$ \\
\hline
\end{tabular}

\subsection{North Gudbrandsdal (NGbr)}

We now turn to the most archaic of the daughter varieties of Old Norse: North Gudbrandsdal. As we saw in section 1.2.1, NGbr allows monomoraic, monosyllabic 
words of the shapes $/ \mathrm{CV}_{\mu} \mathrm{C} /$ and $/ \mathrm{CV}_{\mu} /$. While the $/ \mathrm{CV}_{\mu} \mathrm{C}$ / type is inherited from $\mathrm{ON}$, the $/ \mathrm{CV}_{\mu} /$ type is an innovation specific to NGbr. At the same time NGbr has also preserved light root syllables in disyllabic words, along with MGbr. The trimoraic type has on the other hand been eliminated from the NGbr grammar, as in MGbr and UEN.

The existence of monomoraic words means that in NGbr FoOTBINARITY cannot be top-ranked, since well-formed $/ \mathrm{CV}_{\mu} \mathrm{C} /$ and $/ \mathrm{CV}_{\mu} /$ violate this constraint. In order for monomoraic inputs to survive, we can hypothesize that $\operatorname{DEPLINK}_{\mu}$ must be promoted to top-ranked, above FoOTBINARITY, in order to block expansion of monomoraic inputs into bimoraic. At the same time, $\mathrm{MAXLINK}_{\mu}$ cannot be top-ranked, since trimoraic inputs must be cut down to bimoraic size. The hypothesis would therefore be that a ranking reversal between DEPLINK $\mu$ and FoOTBINARITY is necessary in order to account for the NGbr variety. In addition, within the restricted set of input types and candidates analysed here, there seem to be no arguments for ranking STRESS-TO-WEIGHT and NoCoda on a stratum below FootBinARITY and MAXLINK $\mu$ in this variety. This gives the grammar under (6).

(6) North Gudbrandsdal ranking

DepLink $_{\mu} \gg$ FootBinarity, MaxLink $\mu$, Stress-To-Weight, NoCoda, NonFinALITY (NF) $>>$ ALIGNRIGHT

Tableau 9 evaluates the monomoraic and monosyllabic input types.

Tableau 9: NGbr_Evaluation of monosyllabic, monomoraic inputs

\begin{tabular}{|c|c|c|c|c|c|c|}
\hline & $\mathrm{CV}_{\mu}$ & $\operatorname{DEPLINK}_{\mu}$ & FB & MAXLINK $_{\mu}$ & SW & NoCODA \\
\hline 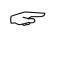 & a) $\left(\mathrm{le}_{\mu}.\right)$ & & * & & * & \\
\hline & b) $\left(\mathrm{le}_{\mu \mu}\right)$ & *! & & & & \\
\hline & c) $\left(\mathrm{le}_{\mu \mu \mu}.\right)$ & $* ! *$ & * & & & \\
\hline & $\mathrm{CV}_{\mu} \mathrm{C}$ & $\operatorname{DEPLINK}_{\mu}$ & FB & $\operatorname{MAXLINK}_{\mu}$ & SW & NoCODA \\
\hline$s$ & d) $\left(s k i_{\mu}\right) n$ & & $*$ & & * & \\
\hline & e) $\left(\mathrm{ski}_{\mu} \mathrm{n}_{\mu}\right) \mathrm{n}$ & $* !$ & & & & $*$ \\
\hline & f) $\left(\mathrm{ski}_{\mu \mu}.\right) \mathrm{n}$ & $* !$ & & & & \\
\hline & g) $\left(\mathrm{ski}_{\mu \mu} \mathrm{n}_{\mu} \cdot\right) \mathrm{n}$ & $* ! *$ & $*$ & & & $*$ \\
\hline
\end{tabular}

We see that top-ranked DePLINK $\mu$ blocks mora insertion in order to make monomoraic inputs comply with lower ranked FoOTBINARITY and STRESS-TO-WEIGHT. That the ranking between DEPLinK $\mu$ and FoOTBINARITY is crucial can be established by a comparison between Tableau 9 and Tableau 8 above. In the latter, FoOTBINARITY above DEPLINK $\mu$ returns the correct bimoraic MGbr output, while the opposite NGbr ranking shown in Tableau 9 ensures that the most faithful candidate wins.

We must also check that the grammar gives the correct result with respect to trimoraic inputs. Here, the lower ranking of the constraint militating against mora 
deletion, MAXLink ${ }_{\mu}$, is powerless, since non-violation will be cancelled by violations incurred by FootBinARity and NoCoDA. This is shown in Tableau 10.

Tableau 10: NGbr-Evaluation of monosyllabic, trimoraic input

\begin{tabular}{|c||c|c|c|c|c|}
\hline $\mathrm{CV}_{\mu \mu} \mathrm{C}_{\mu}$ & DEPLINK $_{\mu}$ & $\mathrm{FB}$ & MAXLINK $_{\mu}$ & $\mathrm{SW}$ & NOCODA \\
\hline \hline a) $\left(\mathrm{na}_{\mu}\right) \mathrm{t}$ & & $*$ & $* ! *$ & $*$ & \\
\hline$\sigma \quad \mathrm{b})\left(\mathrm{na}_{\mu} \mathrm{t}_{\mu}\right) \mathrm{t}$ & & & $*$ & & $* !$ \\
\hline c) $\left(\mathrm{na}_{\mu \mu}\right) \mathrm{t}$ & & & $*$ & & \\
\hline d) $\left(\mathrm{na}_{\mu \mu} \mathrm{t}_{\mu}\right) \mathrm{t}$ & & $*$ & & & $* !$ \\
\hline
\end{tabular}

However, a serious conceptual problem with the grammar under (6) arises by the fact that a faithfulness constraint is top-ranked. The DEP constraint banning moraic epenthesis would seem to have the unwanted consequence that no matter how minimal the input, it will come out as a winner against any candidate which has been expanded by means of mora insertion and which thereby satisfies the most highly ranked markedness constraints. Wholly depending on the input, the grammar under (6) will for instance not only generate words of a bare $\mathrm{CV}_{\mu}$ shape, it will generate words consisting of a consonant only as well. On the assumption that vowels are intrinsically moraic, any candidate generated from a mono-consonantal input with the missing vowel inserted would founder on its violation of DePLiNK $\mu$.

This consequence can be avoided if we assume a higher-ranking templatic word minimality constraint, which can be stated as WDMIN $=\sigma_{\mu}$. This is in clear violation of the commonly assumed principle that a stressable word must minimally correspond to a foot and therefore minimally should consist of two moras. Even if this principle seems logical, Downing (2006) and Gordon (2006) have recently shown that it does not hold up when tested against large and representative samples of different languages. An alternative, suggested by one of the referees, is to assume that the Prosodic Hierarchy, whether hard-wired or implemented by means of a constraint set, will block unwanted sub-minimal winners on the assumption that a foot must consist of at least one syllable.

I leave it to the reader to check that positing this constraint on top of the NGbr constraint hierarchy under (6) will eliminate non-moraic winners from non-moraic inputs by forcing mora insertion in violation of DEPLINK ${ }_{\mu}$. And as we shall see, a similar constraint is needed for Old Norse, to which we now turn. I also leave it to the reader to check against the full NGbr grammar at the companion website that the additional monosyllabic candidates as well as all disyllabic inputs are correctly analysed by the grammar under (6).

\subsection{Old Norse}

Recall from section 1.1 that Old Norse, in contrast with its daughter NGbr, did not tolerate words of a bare $\mathrm{CV}_{\mu}$ shape. The smallest word type in $\mathrm{ON}$ was the monomoraic $\mathrm{CV}_{\mu} \mathrm{C}$ type. Since the final $\mathrm{C}$ is non-moraic, this type cannot be distinguished as a 
prosodic type with respect to weight from the non-existent bare $\mathrm{CV}_{\mu}$ structure. This suggests that a word minimality constraint in ON cannot be stated in prosodic terms only, since this would have to be a monomoraic CV syllable. Instead, we have to include segmental information in the minimality constraint, i.e., as WDMIN $=(C) V_{\mu} C .{ }^{19}$

At the same time, ON allows words with a trimoraic, stressed syllable, a type that has been eliminated from all daughter varieties discussed up to this point. This means that we must promote $\mathrm{MAXLINK}_{\mu}$ in order to block paring of trimoraic inputs down to bimoraic size in order to comply with FOOTBINARITY. Here we run into difficulties similar to those we met with when discussing the effects of top-ranked DEPLINK ${ }_{\mu}$. If not constrained by a higher ranked constraint, not only tri-moraic inputs, but also ill-formed tetra- and penta-moraic inputs etc. would be protected from reduction by top-ranked MAXLinK $\mu$. Note that we cannot assume prosodic maximal word constraints in line with the minimal word constraint just stated, since words may consist of more than one syllable. We are, in other words, dealing with a constraint on maximum syllable size.

While trimoraic syllables consisting of a long vowel plus a moraic consonant are possible in some languages, such as $\mathrm{ON}$, syllables exceeding this size appear to be universally blocked. This can be implemented by means of an inviolable restriction on GEN against syllables with more than three moras. I shall follow this line of reasoning here and assume that candidates with more than four moras in one syllable, like $* / \mathrm{CV}_{\mu \mu \mu} \mathrm{C}_{\mu} /$ or $* / \mathrm{CV}_{\mu \mu} \mathrm{C}_{\mu \mu} /$, are impossible.

Constrained by this ban, I hypothesize that $\mathrm{MAXLINK}_{\mu}$ must be ranked above FOOTBINARITY in Old Norse. This ranking will block the latter from paring trimoraic inputs down to bimoraic size. By adding the word minimality constraint introduced above, the result is the grammar given under (7). With respect to the set of inputs, no arguments can be established for ranking STRESS-TO-WEIGHT below the others, so this grammar is also organized in two strata above AlignRight.

\section{(7) Old Norse ranking}

WDMin $=(\mathrm{C}) \mathrm{V}_{\mu} \mathrm{C}$, MAXLink $_{\mu}$, DepLink $_{\mu}>>$ FootBinarity, Stress-To-Weight, NoCoda, NonFinality $(\mathrm{NF})>>$ AlignRight

Compared to the NGbr grammar discussed in the preceding section, the ON grammar must block derivation of monomoraic $\mathrm{CV}_{\mu}$ outputs, and at the same time allow the most faithful candidates to win with respect to monomoraic $\mathrm{CV}_{\mu} \mathrm{C}$ inputs and trimoraic inputs. Tableau 11 shows how the constraint ranking blocks a bare,

\footnotetext{
${ }^{19}$ See again Downing (2006) for evidence that morphological minimality does not always correspond to prosodic minimality as instantiated by the prosodic hierarchy. One of the referees criticizes the constraint as being non-illuminating, and suggests that its effect instead might be captured in a more principled way by the notion 'branchingness'. This would imply that the final $\mathrm{C}$ is linked to the same mora as the preceding vowel. In the same vein, he rejects the ban against syllables consisting of more than three moras (see immediately below) as unprincipled, and suggests that what I analyse as trimoraic syllables should be analysed as bimoraic, with the final consonant sharing the final mora with the vowel. A full discussion of these options, subsumed under the notion 'branchingness', is not possible within the limits of the present paper. Let it suffice to point out that if we assume that the final consonant in the $\mathrm{CV}_{\mu} \mathrm{C}$ type is moraic, we would without further amendments expect suffixation of a vowel initial suffix to result in a geminate. At the same time, the assumption that the superheavy type is bimoraic would mean that it would satisfy FOOTBINARITY. Since violation of this constraint by trimoraic candidates in my analysis is decisive in some cases, these adjustments would require a complete reworking of the analysis.
} 
monomoraic CV output, and how a bimoraic candidate wins in its place. Tableau 12 shows that the evaluation of trimoraic monosyllabic and disyllabic inputs in both cases renders the most faithful candidates as winners. For all the other input types, the ON grammar derives the same outputs as the NGbr grammar above.

Tableau 11: Old Norse_-Evaluation of monomoraic $\mathrm{CV}_{\mu}$ and $\mathrm{CV}_{\mu} \mathrm{C}$ input

\begin{tabular}{|c|c|c|c|c|c|c|c|}
\hline & $\mathrm{CV}_{\mu}$ & $\begin{array}{c}\text { WDMIN }= \\
(\mathrm{C}) \mathrm{V}_{\mu} \mathrm{C}\end{array}$ & $\operatorname{DEPLINK}_{\mu}$ & MAXLINK $_{\mu}$ & FB & SW & NoCoDA \\
\hline & a) $\left(\mathrm{le}_{\mu}.\right)$ & $*$ & & & * & $* !$ & \\
\hline 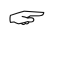 & b) $\left(1 \mathrm{e}_{\mu \mu}.\right)$ & & * & & & & \\
\hline & c) $\left(\mathrm{le}_{\mu \mu \mu}.\right)$ & & $* ! *$ & & $*$ & & \\
\hline & $\mathrm{CV}_{\mu} \mathrm{C}$ & $\begin{array}{l}\text { WDMIN }= \\
(\mathrm{C}) \mathrm{V}_{\mu} \mathrm{C}\end{array}$ & $\operatorname{DEPLINK}_{\mu}$ & $\operatorname{MAXLINK}_{\mu}$ & FB & SW & NoCODA \\
\hline$\infty$ & d) $\left(s k i_{\mu^{\circ}}\right) n$ & & & & * & * & \\
\hline & e) $\left(\mathrm{ski}_{\mu} \mathrm{n}_{\mu}\right) \mathrm{n}$ & & $* !$ & & & & $*$ \\
\hline & f) $\left(s k i_{\mu \mu}.\right) n$ & & $* !$ & & & & \\
\hline & g) $\left(\mathrm{ski}_{\mu \mu} \mathrm{n}_{\mu}.\right) \mathrm{n}$ & & $* ! *$ & & $*$ & & $*$ \\
\hline
\end{tabular}

Tableau 12: Old Norse-Evaluation of trimoraic inputs

\begin{tabular}{|c|c|c|c|c|c|c|c|}
\hline & $\mathrm{CV}_{\mu \mu} \mathrm{C}_{\mu}$ & $\begin{array}{l}\text { WDMIN }= \\
\text { (C) } \mathrm{V}_{\mu} \mathrm{C}\end{array}$ & $\operatorname{DEPLINK}_{\mu}$ & MAXLINK $_{\mu}$ & FB & SW & NoCODA \\
\hline & a) $\left(n a_{\mu}.\right) t$ & & & $* ! *$ & $*$ & $*$ & \\
\hline & b) $\left(n a_{\mu} t_{\mu}\right) t$ & & & $* !$ & & & * \\
\hline & c) $\left(n a_{\mu \mu} \cdot\right) t$ & & & $* !$ & & & \\
\hline$\infty$ & d) $\left(\mathrm{na}_{\mu \mu} \mathrm{t}_{\mu}\right) \mathrm{t}$ & & & & * & & * \\
\hline & $\mathrm{CV}_{\mu \mu} \mathrm{C}_{\mu} \mathrm{V}_{\mu}$ & $\begin{array}{l}\text { WDMIN }= \\
(\mathrm{C}) \mathrm{V}_{\mu} \mathrm{C}\end{array}$ & DEPLINK $_{\mu}$ & MAXLINK $_{\mu}$ & FB & SW & NoCODA \\
\hline & e) $\left(\right.$ ná $\left._{\mu} \cdot \mathrm{te}_{\mu}\right)$ & & & $* ! *$ & & $*$ & \\
\hline & f) $\left(\right.$ ná $\left._{\mu} t_{\mu}.\right) t_{e}$ & & & $* !$ & & & $*$ \\
\hline & g) $\left(\right.$ ná $_{\mu \mu}$.)te $e_{\mu}$ & & & $* !$ & & & \\
\hline$\infty$ & h) $\left(\right.$ ná $\left._{\mu \mu} t_{\mu}\right) \operatorname{te}_{\mu}$ & & & & $*$ & & $*$ \\
\hline
\end{tabular}




\section{The factorial typology}

\subsection{Comparing the partial set of grammars}

In the preceding section I have developed analyses of the quantity system as expressed by mora counts in stressed syllables in Old Norse plus three varieties of modern East Norwegian descendants of Old Norse: Urban East Norwegian, Mid Gudbrandsdal, and North Gudbrandsdal. In this section we shall summarize and discuss the relationship between these grammars in terms of the relationship between the two faithfulness constraints $\mathrm{MAXLINK}_{\mu}$ and DePLINK $\mu$, and the two markedness constraints FootBinARITY and STRESS-TO-WeIGHT in the four grammars. More specifically we shall look at to what extent the relationship between the four grammars, and by implication, the relationship between Old Norse and the modern grammars, can be accounted for by the Factorial Typology hypothesis introduced in section 2 above.

The four grammars are summarized in (8). Only the four constraints whose interaction determines quantity as measured by how many moras a syllable consists of have been included, and the order of the grammars has been reversed with respect to the orders in which they were treated in section $4 .{ }^{20}$ The first line therefore shows the diachronically most ancient grammar, Old Norse.

(8) Hypothetical development from Old Norse to Urban East Norwegian

$$
\begin{aligned}
& \text { ON: DepLink } \mu, \text { MaxLinK }_{\mu}>>\text { FootBinarity, Stress-to-Weight } \\
& \text { NGbr: DePLinK }{ }_{\mu}>>\text { FootBinarity, } \text { MAXLINK }_{\mu}>>\text { STRESS-To-WeIGHT }^{2} \\
& \text { MGbr: FootBinarity }>>\text { DePLinK }_{\mu}, \text { MAXLinK }_{\mu}>>\text { Stress-To-Weight } \\
& \text { UEN: FootBinarity, Stress-To-Weight }>>\text { DePLinK }_{\mu}, \text { MAXLINK }_{\mu}
\end{aligned}
$$

The modern grammars have then been ordered by the degree of distance from the Old Norse origin. The order in (8) thereby represents an idealized hypothesis of the minimal stages that the language may have passed through on its way from Old Norse to Urban East Norwegian. ${ }^{21}$ The two markedness constraints have been bolded in order to better visualize the development from one idealized stage to the next. In this way (8) shows how what we with Morén $(2000,2001)$ may refer to as coercive weight has become progressively more dominant in the development from Old Norse into the modern Post-Prokosch East Norwegian dialects. In Old Norse, FoOTBINARITY and STRESS-TO-WEIGHT were both ranked below the two faithfulness constraints. In UEN they are both ranked above the faithfulness constraints, and will thereby coerce all stressed syllables into bimoraic shape. (8) also shows how NGbr and MGbr can be seen as representatives of intermediate stages if the change from

\footnotetext{
$\overline{{ }^{20} \text { Two of the referees criticized }}$ me for not including all the constraints introduced in section 3 in the typology. I shall return to this point in section 7 below.

${ }^{21}$ It should be noted that UEN is commonly regarded as having inherited several structural features from the Dano-Norwegian spoken by Danish civil servants and their descendants during the 400 years that Norway was part of the kingdom of Denmark, a period which ended in 1814. Since Danish quantity is unlike Norwegian and Swedish quantity, see, e.g., Riad (1995) and Basbøll (2005), and since UEN is like most rural East Norwegian dialects in this respect, it is hardly probable that differences between UEN and the other varieties in (8) should be due to Danish influence.
} 
ON into modern dialects as represented by UEN is conceptualized as a stepwise reranking of the constraints involved.

As pointed out by one of the referees, however, it is not possible to prove that MGbr and UEN actually went through a 'NGbr' stage and that UEN in addition passed through a 'MGbr' stage on their way to the actually attested systems. The main point is therefore that the idealized stages characterized by each grammar, which again represent different permutations of the same set of constraints, are attested, and that a structurally welldefined model of a trajectory between ON and UEN can be posited.

At the same time, the grammars derived up until now do not represent the exhaustive set of grammars that can be derived from all possible permutations of the four constraints. This is where the Factorial Typology concept introduced in section 2 becomes relevant.

\subsection{The full typology}

As discussed in section 2, a factorial typology is the exhaustive set of empirically different grammars that results from all possible rankings of a certain set of constraints. To the extent that language change is reranking of constraints, a factorial typology thereby by hypothesis delimits the set of possible grammars that can result from a change consisting of one or more permutations of these constraints. This means that had the rankings under (8) represented the full range of different rankings, the two intermediate types along with ON and UEN as starting and ending points would have exhausted the possible change space defined by these constraints. This is not necessarily so, however. Since we have four different and in principle independent constraints, the logical number of possible rankings is 24 . On the other hand, not all of these rankings will necessarily be different with respect to their empirical predictions.

I have used the OTSoft software to identify the set of different grammars that can be constructed from the four constraints. ${ }^{22}$ The data set used as input was established in the following way: The set of inputs, based on the UEN data set, was reduced by (i) eliminating extrametricality in order to abstract away from the influence of NonFInALITY, and (ii) by eliminating CVC as an alternative way of instantiating bimoraicity in addition to $\mathrm{CVV}$ in order to abstract away from the influence of NoCoDA. The resulting candidate table submitted to the OTSoft algorithm is reproduced at the companion website.

The output returned by the algorithm consists of 6 empirically different grammars. These grammars, referred to as Outputs \#1-\#6, are reproduced in Table 6. For clarity, the winning candidates where mono- or trimoraicity has been preserved have been bolded. The attested and (with respect to East Norwegian) non-attested grammars are signalled in the first line of the table, the latter by a question mark after the number of the variety.

The two grammars not attested are both characterized by faithful preservation of trimoraicity in the input, while monomoraic inputs are only partially preserved. This

\footnotetext{
${ }^{22}$ OTSoft (Hayes 2003; Hayes et al. 1993) is a software that can be used to test a given analysis for internal coherence and validity. It also comprises a function that from a given candidate set and a given set of constraints returns the factorial typology defined by these constraints.
} 
Table 6 Factorial typology defined by the four constraints

\begin{tabular}{|c|c|c|c|c|c|c|}
\hline Output & $\# 1:$ UEN & $\# 2:$ ? & $\# 3: M G b r$ & $\# 4: N G b r$ & $\# 5: ?$ & $\# 6: O N$ \\
\hline \multicolumn{7}{|l|}{ Input } \\
\hline /CVVCV/: & $(\mathrm{CVV}) \mathrm{CV}$ & $(\mathrm{CVV}) \mathrm{CV}$ & $(\mathrm{CVV}) \mathrm{CV}$ & $(\mathrm{CVV}) \mathrm{CV}$ & $(\mathrm{CVV}) \mathrm{CV}$ & $(\mathrm{CVV}) \mathrm{CV}$ \\
\hline /CVCCV/: & $(\mathrm{CVC}) \mathrm{CV}$ & $(\mathrm{CVC}) \mathrm{CV}$ & $(\mathrm{CVC}) \mathrm{CV}$ & $(\mathrm{CVC}) \mathrm{CV}$ & $(\mathrm{CVC}) \mathrm{CV}$ & $(\mathrm{CVC}) \mathrm{CV}$ \\
\hline /CVCV/: & $(\mathrm{CVV}) \mathrm{CV}$ & $(\mathrm{CVV}) \mathrm{CV}$ & (CVCV) & $(\mathrm{CVCV})$ & $(\mathrm{CVCV})$ & (CVCV) \\
\hline /CVVCCV/: & $(\mathrm{CVV}) \mathrm{CV}$ & $(\mathrm{CVVC}) \mathrm{CV}$ & $(\mathrm{CVV}) \mathrm{CV}$ & $(\mathrm{CVV}) \mathrm{CV}$ & $(\mathrm{CVVC}) \mathrm{CV}$ & $(\mathrm{CVVC}) \mathrm{CV}$ \\
\hline /CVCC/: & $(\mathrm{CVC}) \mathrm{C}$ & $(\mathrm{CVC}) \mathrm{C}$ & $(\mathrm{CVC}) \mathrm{C}$ & $(\mathrm{CVC}) \mathrm{C}$ & $(\mathrm{CVC}) \mathrm{C}$ & $(\mathrm{CVC}) \mathrm{C}$ \\
\hline /CVVC/: & $(\mathrm{CVV}) \mathrm{C}$ & $(\mathrm{CVV}) \mathrm{C}$ & $(\mathrm{CVV}) \mathrm{C}$ & $(\mathrm{CVV}) \mathrm{C}$ & $(\mathrm{CVV}) \mathrm{C}$ & $(\mathrm{CVV}) \mathrm{C}$ \\
\hline /CVV/: & $(\mathrm{CVV})$ & $(\mathrm{CVV})$ & $(\mathrm{CVV})$ & $(\mathrm{CVV})$ & $(\mathrm{CVV})$ & $(\mathrm{CVV})$ \\
\hline /CVVCC/: & $(\mathrm{CVV}) \mathrm{C}$ & $(\mathrm{CVVC}) \mathrm{C}$ & $(\mathrm{CVV}) \mathrm{C}$ & $(\mathrm{CVV}) \mathrm{C}$ & $(\mathrm{CVVC}) \mathrm{C}$ & $(\mathrm{CVVC}) \mathrm{C}$ \\
\hline$/ \mathrm{CVC} /:$ & $(\mathrm{CVV}) \mathrm{C}$ & $(\mathrm{CVV}) \mathrm{C}$ & $(\mathrm{CVV}) \mathrm{C}$ & $(\mathrm{CV}) \mathrm{C}$ & $(\mathrm{CVV}) \mathrm{C}$ & $(\mathrm{CV}) \mathrm{C}$ \\
\hline /CV/: & $(\mathrm{CVV})$ & $(\mathrm{CVV})$ & $(\mathrm{CVV})$ & $(\mathrm{CV})$ & $(\mathrm{CVV})$ & (CV) \\
\hline
\end{tabular}

implies that MAXLink ${ }_{\mu}$ is top ranked in these grammars, while DEPLINK $\mu$ is lower ranked. They can informally be characterized as the UEN and MGbr systems with preserved trimoraic stressed syllables. ${ }^{23}$ As can be seen from the grammar set under (8), grammars with this property are lacking among the East Norwegian varieties analysed above.

As it turns out, however, both of these are indeed attested outside the East Norwegian area. Output \#2 is identical with the West Norwegian Setesdal dialect, spoken further south in Southern Norway (Storm 1884: 66; Hannaas 1921; Skomedal 1972). Here monomoraic stress has been consistently expanded to bimoraic, while the trimoraic type has been preserved. Output \#5, a system like the MGbr system, with preserved monomoraic stress in CVCV words, consistent bimoraicity in monosyllabic words, and in addition preserved trimoraic stress, is attested in the Dalarna region of Sweden. According to Levander (1925: 75ff) there are three dialects where trimoraic stressed syllables have been preserved in this region. Two of these, Öje and Sollerön, have consistently eliminated the monomoraic type, and therefore belong to the same type as Setesdal. But in the third one, the Älvdalen dialect, monomoraic monosyllabic words have expanded to bimoraic, while monomoraicity has been retained in CVCV-structures. The Älvdalen dialect therefore corresponds to the missing \#5-type in Table 6.

The full set of grammars can now be listed as in (9), where the numbering of outputs has been altered in order to better represent the minimal stages between Old Norse and UEN.

(9) The full typology

\#1 (ON): DepLink $\mu$, MaxLinK $_{\mu}>$ FootBinarity, Stress-to-Weight

\#2 (NGbr): DepLinK $\mu$ > FootBinarity, Stress-to-Weight, MaxLinK $\mu$

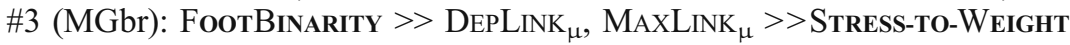

\footnotetext{
${ }^{23}$ Disregarding the different word minimality constraints, the extension of this reasoning to a NGbr grammar with preserved trimoraic stress would be identical with the ON system.
} 
\#4 (Älvdalen): MAXLinK $_{\mu}>$ FootBinarity, DePLinK ${ }_{\mu}>>$ Stress-To-Weight

\#5 (Setesdal): MaxLink $_{\mu}$, Stress-To-Weight $>>$ FootBinarity, DePLinK $\mu$ \#6 (UEN): FootBinarity, Stress-to-Weight $>>$ DePLinK $_{\mu}$, MaxLinK $_{\mu}$

A further analysis of (9) reveals that there are three possible paths of stepwise, minimal rerankings between Old Norse and UEN. The first, manifested by the trajectory through NGbr, consists of a gradual demotion of $\mathrm{MAXLINK}_{\mu}$ followed by a later demotion of $\mathrm{DEPLINK}_{\mu}$ in the grammar of MGbr. Here, trimoraicity is eliminated before monomoraicity (NGbr). Then monomoraic monosyllables go (MGbr), and finally elimination of monomoraicity in disyllables results in the modern system represented by UEN. The second path, attested by the Älvdalen and Setesdal developments, consists of an initial demotion of DEPLINK ${ }_{\mu}$ followed by a later demotion of MAXLINK $\mu$. Along this path, monomoraicity in monosyllables is eliminated first, resulting in the Älvdalen system. Next monomoraicity in disyllabic word goes, leading into the Setesdal system. When trimoraic syllables finally are reduced to bimoraicity, the result again is the modern system with only bimoraic syllables. The third possible path also has Älvdalen as the initial stage. But here, demotion of $\mathrm{MAXLINK}_{\mu}$ leads to elimination of trimoraic syllables, leaving disyllabic words with monomoraic stress as the only difference with respect to UEN. This is the MGbr system.

While it is interesting and significant in itself that four out of four possible intermediate stages between the Old Norse and the modern system are attested, it is even more important that no system seems to be attested that lies outside the change space defined by permutations in the ranking of the four constraints. ${ }^{24}$

Logically we can think of three such developments: (i) moraic expansion of the stressed syllable in disyllabic CVCV domains without concomitant expansion in monosyllabic words, (ii) elimination of trimoraic syllables only in monosyllabic words and not in disyllabic words, and (iii) elimination of trimoraic syllables only in disyllabic words and not in monosyllabic words. A priori, these are all conceivable developments, but they are excluded by the grammars defined above. This is in each case due to FOOTBINARITY, which will penalize monomoraic, monosyllabic words but not $\mathrm{CV}_{\mu} \cdot \mathrm{CV}_{\mu}$ words, since only the latter represents a well-formed trochee. With respect to (ii) and (iii), the constraint will not distinguish between mono- and disyllabic inputs, since in both cases it is the stressed syllable that exceeds the maximum defined by the constraint.

This renders a total of seven possible intermediate stages between ON and UEN, of which four are predicted by the analysis, while the remaining three are predicted not to occur. The fact that the observed variation perfectly accords with the predictions made by the model strongly suggests that the four constraints are not only descriptively adequate with respect to each synchronic stage, but that they also

\footnotetext{
${ }^{24}$ The only divergent development I'm aware of has taken place in the dialects of Tinn in Upper East Telemark and in the East Mora dialect in the Dalarna region (Kristoffersen 2010). In both, $\mathrm{CV}_{\mu} \mathrm{CV}_{\mu}$ words have developed final, bimoraic stress, in Tinn in synchronic variation with preserved $\mathrm{CV}_{\mu} \mathrm{CV}_{\mu}$ and initial heavy stress (Skulerud 1922: 120), and in East Mora consistently (Levander 1925: 55 f.; Kristoffersen 2010). But note that final heavy stress is another instantiation of a Post-Prokosch system. The difference from the dialects discussed in this paper is primarily one of stress placement.
} 
have real explanatory force in that they seem to make correct predictions with respect to what is not a possible development.

\subsection{Hesselman's law}

My analysis precludes moraic expansion in disyllabic $\mathrm{CV}_{\mu} \mathrm{CV}_{\mu}$ words without concomitant expansion in monomoraic monosyllabic $\mathrm{CV}_{\mu}(\mathrm{C})$ words. On the other hand, $\mathrm{CV}_{\mu}(\mathrm{C})$ words may expand without simultaneous expansion in disyllabic words, as witnessed by the MGbr system. In diachronic studies of North Germanic quantity, this relationship, termed Hesselman's law by Riad (1992), has been noted and interpreted to the effect that expansion in monosyllabic words has taken place before expansion in disyllabic words (Hesselman 1902; Küspert 1988: 163; Riad 1992: 271; Kusmenko 1995: 84; Page 2001).

But, as pointed out by one of the referees, the hypothesis that language change comes about through children's imperfect reconstruction of the grammar underlying the ambient linguistic input does not logically depend on any change being limited to a minimal adjustment in a diachronic grammar modelling the change. Therefore, we must also be open to the possibility that moraic expansion in monosyllabic and disyllabic words can have taken place simultaneously, as pointed out by Seiler (2009).

What should not be possible is the opposite order; disyllabic before (i.e., without) monosyllabic expansion. We have already noted that this state of affairs does not seem to have arisen in Norwegian and Swedish. But changes reminiscent of the North Germanic quantity shift have also taken place in West Germanic varieties. In a recent paper, Seiler (2009: 239), contends that there are arguments in favour of this having taken place in Low German and in at least one Upper German dialect, viz. Uri (High Alemanic). With respect to Low German, the crucial data area of the alternation type found in, for example, Standard Dutch between short vowel in the monosyllabic realizations of etymologically monomoraic stems, against lengthened vowel in the corresponding disyllabic suffixed instantiations of the same stem. An example is /dax/ /da:xen/, day days.

A thorough examination of the available evidence, especially dialect data from Low German, would exceed the limits of the present paper. But it can be mentioned that modern Dutch according to Booij (1995) does not allow for geminate consonants. According to Seiler (2009: 232), a postvocalic moraic consonant is a geminate. This would seem to imply that in order for a language to have moraic consonants, it must have a contrast between singletons and geminate consonants. Taken at face value, this would imply that the final consonant in /dax/ cannot be moraic, and that Standard Dutch therefore constitutes counterevidence to the claim that lengthening can take place in disyllables without concomitant lengthening in monosyllables.

This interpretation that a moraic consonant always is a geminate seems to me to be too strong, however. A better way to state the relationship between geminates and moraic status would be to say that in cases where a language distinguishes between singletons and geminates, this contrast can be modelled as one between non-moraic and moraic consonants. Moraic status of postvocalic consonants in languages that lack this distinction must then be based on other types of evidence, e.g., Weight-by- 
Position. Indeed, Gussenhoven (2009) claims that Dutch VC-rhymes are heavy due to $\mathrm{WbP}$.

The heaviness of VC-rhymes is not obvious, but can be seen in trisyllabic words. [...] The atypical 'fact' that closed syllables are heavy and longvowelled open syllables light can be seen by comparing words of the type almanac 'almanac' with words like Gibraltar 'id.' Both of these have a closed final syllable, but they differ in the structure of the penult. The closed penult attracts stress, leading to [xi'braltar], while the open penult is regularly skipped, causing main stress on the antepenult. The above interpretation of vowel quantity thus gives rise to the belief that long vowels, like [a:] in ['alma:nak], are light, even though closed syllables are heavy. (Gussenhoven 2009)

To the extent that this is correct there seems to be no reason to assume that the postvocalic consonant in /dax/ is non-moraic, and the word consequently monomoraic. In fact, if Booij (1995) is right and Standard Dutch does not allow geminates, then the change into a long vowel in the suffixed form may be explained by this. By this reasoning at least Standard Dutch can be removed from the list of potential violators of the principle in question.

The other possible exception is the Upper German dialect of Uri (Clauss 1929). Here we also find non-lengthened monosyllables along with lengthening in disyllabic words (p. 163). However, Seiler notes that in monosyllables "[...] the final consonant is geminated pre-pausally". This opens the door for an alternative interpretation where the monosyllables in fact have lengthened by moraification of the final consonant, as in East Norwegian and in Dutch. This underlying form will surface unchanged before a pause, but in environments where the addition of another vowel in a following word will allow for building a foot across the word boundary, an alternative way of satisfying FOOTBINARITY becomes available and degemination can take place, cf. Kusmenko (1995: 84f.).

Based on these arguments I contend that the potential counterevidence from German varieties against the implication of my analysis that moraic expansion in disyllables cannot take place without concomitant expansion in monosyllables is far from decisive.

\section{Extending the coverage}

Several of the systems listed in (9) have only been attested so far in one dialect. However, there are several other Swedish dialects, in as well as outside Dalarna, where monomoraic root syllables have been preserved.

In Dalarna, we may, according to Levander (1925: 64f.), add other dialects to one of the intermediary types in (9) in addition to Älvdalen. Except for Öje and Sollerön, which as mentioned belong to the Setesdal type, these are of the MGbr type, where monosyllabic words have been expanded and trimoraic words reduced. Examples are Skattungbyn (Kristoffersen 2010) in the Orsa municipality and Våmhus in the Mora municipality.

As to the rest of Sweden proper, most introductory texts and overviews of Swedish dialects identify preserved light root syllables as a northern feature. 
However, it is difficult to find detailed overviews. The sources I have consulted give a list of landscape names where light root syllables are found, without distinguishing between monosyllabic and disyllabic words and without listing local dialects within these regions. ${ }^{25}$ I suspect that monomoraicity in most of these dialects is restricted to CVCV forms. Depending on the fate of the trimoraic words, these dialects therefore will belong either to the Älvdalen type (with preserved trimoraic root syllables) or to the MGbr type (with shortened trimoraic root syllables).

The best documented of these is the Kalix dialect, spoken in the extreme north near the Finnish border. The detailed data given in Söderström (1972) clearly confirms that monosyllabic $\mathrm{CV}_{\mu} \mathrm{C}$ words are still (or were until recently) wellformed in both the Upper and Lower Kalix dialects and to a lesser degree in neighbouring dialects. But there is a fair amount of variation, among other things conditioned by the quality of the root vowel (/a/ has been almost consistently lengthened, as in NGbr), and by the following consonant (less lengthening before voiceless obstruents than before voiced consonants). With respect to the CVCV type, Söderström's data show almost consistent preservation of the light root syllable.

As to the fate of trimoraic forms, neither Söderström nor another source on the Upper Kalix dialect, Pihl (1924), treat this point in a way precise enough to draw secure conclusions. But the discussion of the vowel quality in four words with etymological trimoraicity on page $214 \mathrm{f}$. in Pihl (1924) suggests that shortening has taken place; all four words are transcribed with short vowel and geminate consonant. Likewise, Söderström (1972: 18) refers to shortening of trimoraic syllables, but without mentioning whether this is systematic or sporadic. This suggests that the Kalix dialect group belongs to the NGbr type, although without the bare $\mathrm{CV}_{\mu}$ type that developed in NGbr. The variation with respect to the monosyllabic type, with a fair number of words having lengthened, suggests that the dialect is in the process of developing into the MGbr type, where light root syllables are only allowed in disyllabic CVCV words.

We finally turn to the Swedish dialects spoken along the western and southern coast of Finland and on the Estonian coast (the latter until World War II). One of the features that are commonly seen as strongly characterizing these dialects is preserved light root syllables, both in monosyllabic and disyllabic domains. In addition, trimoraic root syllables have been preserved in a fair number of dialects. But there are also varieties where Prokosch's law has been fully implemented. The dialect information in Table 7 has been extracted from Hultman (1894), while the information behind the classification of the standard Finland Swedish spoken in Helsingfors [Helsinki] and taught in schools throughout the Swedish speaking regions in Finland, is from Ahlbäck (1956: 31). The dialects are listed from north to south. It is otherwise organized in the same way as the East Norwegian overview in Table 5 in section 1.2.4, with a column added indicating dialect type according to the factorial typology in (9) above. ${ }^{26}$

Also in Finland, monosyllabic, monomoraic words with /a/ as root vowel have generally been lengthened in dialects where this type has been otherwise preserved

\footnotetext{
${ }^{25}$ One such list can be found in Söderström (1972: 9).

${ }^{26}$ The $\mathrm{CV}_{\mu}$ column has been removed, since this type is restricted to NGbr.
} 
Table 7 Finland and Estonia Swedish: Summary of dialect differences with respect to structural options for root syllable in monosyllabic and disyllabic words

\begin{tabular}{|c|c|c|c|c|c|c|}
\hline & \multirow[t]{2}{*}{ Type } & \multicolumn{2}{|l|}{ Light } & \multicolumn{2}{|l|}{ Heavy } & \multirow{2}{*}{$\begin{array}{l}\text { Trimoraic } \\
\mathrm{CV}_{\mu \mu} \mathrm{C}_{\mu}\end{array}$} \\
\hline & & $\mathrm{CV}_{\mu} \mathrm{C}$ & $\mathrm{CV}_{\mu} \cdot \mathrm{CV}_{\mu}$ & $\mathrm{CV}_{\mu \mu}$ & $\mathrm{CV}_{\mu} \mathrm{C}_{\mu}$ & \\
\hline North-Österbotten & \#1 (Old Norse) & $\sqrt{ }$ & $\sqrt{ }$ & $\sqrt{ }$ & $\sqrt{ }$ & $\sqrt{ }$ \\
\hline Mid-Österbotten & \#4 (Älvdalen) & & $\sqrt{ }$ & $\sqrt{ }$ & $\sqrt{ }$ & $\sqrt{ }$ \\
\hline South-Österbotten & \#3 (MGbr) & & $\sqrt{ }$ & $\sqrt{ }$ & $\sqrt{ }$ & \\
\hline Åland & \#6 (UEN) & & & $\sqrt{ }$ & $\sqrt{ }$ & \\
\hline Standard Fenno Sw. & \#6 (UEN) & & & $\sqrt{ }$ & $\sqrt{ }$ & \\
\hline Nyland, East Åboland & \#1 (Old Norse) & $\sqrt{ }$ & $\sqrt{ }$ & $\sqrt{ }$ & $\sqrt{ }$ & $\sqrt{ }$ \\
\hline Estonian Swedish & \#4 (Älvdalen) & & $\sqrt{ }$ & $\sqrt{ }$ & $\sqrt{ }$ & $\sqrt{ }$ \\
\hline
\end{tabular}

(Hultman 1894: 131). Otherwise, we see that except for the NGbr and the Setesdal type, all the grammars listed in (9) are attested in Finland and Estonian Swedish. ${ }^{27}$

The map in Fig. 3 shows the approximate geographical distribution of the different types. ${ }^{28}$ All the numbers refer to geographically limited areas, named in each case. All varieties outside these areas are Post-Prokosch varieties.

\section{An expanded typology}

Two of the anonymous referees criticized the first version of this paper for limiting the factorial typology to the four constraints FoOTBINARITY, STRESS-TO-WEIGHT, DEPLINK $_{\mu}$ and MAXLINK grammars developed in section 4, NoCoDA and NonFinality. While I accept the criticism and the need to discuss the issue in a more explicit way than was done in the earlier version, I still think that limiting the factorial typology analysis to the four constraints is methodologically justified. There are two reasons for this.

The first is that the focus of the paper is on the interaction and tension between markedness constraints governing quantity as expressed by mora count in stressed syllables and foot structure, and faithfulness constraints protecting moraic structure in the input. Let me refer to the first pair as the two metrical constraints, enforcing bimoraicity at the syllable and foot level.

\footnotetext{
${ }^{27}$ In a recently published study on Fenno-Swedish quantity, Paul Kiparsky (2008) arrives at a similar distribution. Since his main data source, Harling-Kranck and Mara (1998) is about 100 years younger than the one used here (Hultman 1894), the geographical distribution is somewhat different. But the three types marked on the Finland part of the map in Figure 3 correspond to the three types Kiparsky arrives at in his analysis, termed General, S.Ostrob. and S.W. (p. 197). Kiparsky's paper only came to my attention during the final revision process of this paper. He employs the same markedness constraints that I do-FoOT-BINARITY and Stress-TO-WeIght, but derives vowel length by means of CONSONANT EXTRAMETRICALITY instead of NoCoDA. His faithfulness constraints are DEP-V $\mu$ and MAX- $\mu$. Kiparsky's analysis also comprises postvocalic consonant fortition processes which are outside the scope of the present paper. In addition, he includes as a crucial part of his analyses the fact that the standard Helsingfors variety allows light stressable syllables in function words, while demanding bimoraic stressed syllables in content words.

${ }^{28}$ The basic map is an excerpt of a map published in the Norwegian version of Wikipedia (http://no. wikipedia.org/wiki/Nordiske_språk) with information added by the author.
} 
NoCoDA is different. It is also a markedness constraint, but its function is orthogonal to that of the metrical constraints in that it is concerned with whether bimoraicity is realized by means of a long vowel or a moraic consonant/geminate. Another argument against including NoCODA is that in the grammars where it is topranked, or in fact ranked above the faithfulness constraints, the result will be grammars that are not empirically justified with respect to the North Germanic varieties that are the topic of this paper. As can be seen from Tableau 1 above, highly ranked NoCoda will eliminate the $\mathrm{CV}_{\mu} \mathrm{C}_{\mu}$ type entirely, forcing it into $\mathrm{CV}_{\mu \mu} . \mathrm{C}$ or $\mathrm{CV}_{\mu} \cdot \mathrm{C}$ shape. Dialects where closed heavy syllables are prohibited and where bimoraicity in stressed vowels invariably is realized through vowel length do not, to the best of my knowledge, exist in North Germanic.

NONFINALITY, being primarily concerned with stress placement, is also orthogonal to the questions of quantity change pursued in this paper. It will decide between candidates of the form $\mathrm{CV}_{\mu \mu} \cdot \mathrm{C}$ and $\mathrm{CV}_{\mu \mu} \mathrm{C}$ in favour of the former, due to the status of the final $\mathrm{C}$ as the onset of a deficient syllable. The same holds for the candidate pair $\mathrm{CV}_{\mu} \cdot \mathrm{C}$ against $\mathrm{CV}_{\mu} \mathrm{C}$. In both cases, the number of moras in the competing candidate pairs is the same. Note incidentally that if NoCODA is highly enough ranked, it will also eliminate the second member of each pair from the competition.

While these arguments appear to me as valid reasons for excluding the two constraints from the main analysis, I agree with the referees that it should all the same be shown explicitly that this move does not have unforeseen and dire effects on the analysis. A factorial typology including all six constraints should therefore be checked for possibly unforeseen and unfavourable consequences. One of the referees has in fact most generously provided me with the analysis. As the following quotation from his or her evaluation shows, extension of the analysis to six constraints does not introduce any harmful effects into the analysis:

[A]ll additional predicted quantity systems seem to be natural extensions of the basic set; none defeat the author's claims about the basic constraint set's restrictiveness. Hence, overall this is a good result that should be reported in the article; it should comfort readers like myself who feel uneasy about leaving two major constraints out of the typology.

The candidate set and analysis can be consulted at the companion website of this paper. While the four constraints results in six different grammars, as shown in section 5.2, the software returns a set of 14 grammars. But as noted by the referee, no unexpected and unwanted consequences with respect to the restrictiveness of the analysis arise. NoCoDA has results predicted above, in that $\mathrm{CV}_{\mu} \mathrm{C}_{\mu} \mathrm{V}_{\mu}$ depending on the grammar is turned into $\mathrm{CV}_{\mu \mu} \mathrm{CV}_{\mu}$, or $\mathrm{CV}_{\mu} \mathrm{CV}_{\mu}$, while $\mathrm{CV}_{\mu} \mathrm{C}_{\mu}$ is turned into $\mathrm{CV}_{\mu \mu}$. C. NonFInALITY results in $\mathrm{CV}_{\mu} \mathrm{CV}_{\mu}$ being realized as non-final $\left(\mathrm{CV}_{\mu}\right) \mathrm{CV}_{\mu}$ instead of $\left(\mathrm{CV}_{\mu} \mathrm{CV}_{\mu}\right)$.

\section{Summary and conclusion}

In this article I have shown that the development from distinctive quantity in Old Norse and Old Swedish into coercive quantity in Modern Norwegian and Swedish can be modelled by means of four constraints, DePLinK $\mu$, MAXLinK $_{\mu}$, FootBinarity, and Stress-TO-Weight, and the complete set of possible, empirically distinct ranking 
relationships between them. By limiting the analysis to different varieties of East Norwegian at the outset, I showed that the three different varieties which exhaust the variation space in this area with respect to syllable quantity, North Gudbrandsdal, Mid Gudbrandsdal, and Urban East Norwegian, can be derived from Old Norse by means of gradual demotion of the two faithfulness constraints. I then derived a factorial typology of the four constraints, and was able to show that the two remaining grammars derived by the algorithm, not attested in East Norwegian, are in fact attested elsewhere in peninsular North Germanic and in Fenno-Swedish. Table 8 summarizes the findings, and supplies the complete list of dialects belonging to each type that I have been able to identify.

The four constraints can be seen as well established in the literature, even if the twist where faithfulness is defined over moraic links and not the presence or absence of moras themselves may be somewhat unusual. But DePLinK $\mu$ and $\mathrm{MAXLINK}_{\mu}$ do the same job as the more traditional $\mathrm{DEP}_{\mu}$ and $\mathrm{MAx}_{\mu}$, and in addition they ensure that reorganization of the moraic structure of a given input is penalized, even if the number of moras in the input and a given output candidate correspond to each other. The analysis can therefore be seen as (added) evidence for the central relevance of the four constraints in prosodic analyses, irrespective of how the two faithfulness constraints are defined.

This claim is reinforced by the fact that the factorial typology based on the four constraints not only exhaustively captures the attested developments in Norwegian and Swedish dialects, but also that developments which are not created by the factorial typology defined by the four constraints do not seem to be attested. As mentioned above, it is easy to conceive of such developments, but they can neither be accounted for by the grammars developed in this paper, nor do they, as just noted, seem to be attested.

The development that I have charted from Old Norse into the different modern varieties of Norwegian and Swedish is a monotonic one from full distinctive quantity in the old varieties, where mono- or bimoraicity in vowels could be freely combined with moraic consonants (or absence of such) in stressed syllables, into the modern coercive systems defined by strict bimoraicity in stressed syllables. It should be noted that this directionality itself is not a necessary feature of the relationship

Table 8 Distribution of dialects across the six grammars ( $\mathrm{N}=$ Norway, $\mathrm{S}=$ Sweden, $\mathrm{F}=$ Finland $)$

\begin{tabular}{|c|c|c|c|c|c|c|}
\hline \multirow[t]{2}{*}{ Grammar } & \multirow[t]{2}{*}{ Dialects } & \multicolumn{2}{|l|}{ Light } & \multicolumn{2}{|l|}{ Heavy } & \multirow{2}{*}{$\mathrm{CV}_{\mu \mu} \mathrm{C}_{\mu}$} \\
\hline & & $\mathrm{CV}_{\mu} \mathrm{C}$ & $\mathrm{CV}_{\mu} \cdot \mathrm{CV}_{\mu}$ & $\mathrm{CV}_{\mu \mu}$ & $\mathrm{CV}_{\mu} \mathrm{C}_{\mu}$ & \\
\hline \# 1 & $\begin{array}{l}\text { Old Norse, North Österbotten (F), } \\
\text { Nyland (F) }\end{array}$ & $\sqrt{ }$ & $\sqrt{ }$ & $\sqrt{ }$ & $\sqrt{ }$ & $\sqrt{ }$ \\
\hline$\# 2$ & North Gudbrandsdal (N), Kalix (S) & $\sqrt{ }$ & $\sqrt{ }$ & $\sqrt{ }$ & $\sqrt{ }$ & \\
\hline \# 3 & $\begin{array}{l}\text { Mid Gudbrandsdal (N), East Telemark (N) } \\
\text { Våmhus (S), Skattungbyn (S), South } \\
\text { Österbotten (F) }\end{array}$ & & $\sqrt{ }$ & $\sqrt{ }$ & $\sqrt{ }$ & \\
\hline \# 4 & $\begin{array}{l}\text { Älvdalen (S), Mid Österbotten (F), } \\
\text { Estonian Swedish }\end{array}$ & & $\sqrt{ }$ & $\sqrt{ }$ & $\sqrt{ }$ & $\sqrt{ }$ \\
\hline \# 5 & Setesdal (N), Sollerön (S), Öje (S) & & & $\sqrt{ }$ & $\sqrt{ }$ & $\sqrt{ }$ \\
\hline \# 6 & $\begin{array}{l}\text { Urban East Norwegian, Standard Swedish, } \\
\text { Standard Finland Swedish, Åland (F) }\end{array}$ & & & $\sqrt{ }$ & $\sqrt{ }$ & \\
\hline
\end{tabular}


between the four constraints. On the contrary, the principle of free ranking predicts that we would find languages that develop in the opposite direction. An investigation of this, however, lies outside the scope of the present paper.

Acknowledgements I would like to thank the four anonymous referees and the editor of The Journal of Comparative Germanic Linguistics for valuable and constructive criticism of the first version of the paper. Not all of their advice has been followed nor commented upon in the text. But they have all contributed to sharpening my thinking about the phenomenon under discussion and numerous improvements are due to them. The responsibility for remaining errors, inconsistencies, and sloppy thinking is wholly mine.

Open Access This article is distributed under the terms of the Creative Commons Attribution Noncommercial License which permits any noncommercial use, distribution, and reproduction in any medium, provided the original author(s) and source are credited.

\section{References}

Ahlbäck, Olav. 1956. Svenskan i Finland. Stockholm: Norstedts.

Basbøll, Hans. 1998. Nyt om stødet $i$ moderne rigsdansk. Institut for Sprog og Kommunikation: Odense Universitet. 35.

Basbøll, Hans. 2005. The phonology of Danish. Oxford: Oxford University Press.

Booij, Geert. 1995. The phonology of Dutch. Oxford: Clarendon Press.

Bruce, Gösta. 1998. Allmän och svensk prosodi. Lund: Institutionen för lingvistik, Lunds universitet.

Bruce, Gösta, and Eva Gårding. 1978. A prosodic typology for Swedish dialects. In Nordic prosody, ed. E. Gårding, G. Bruce, and R. Bannert, 219-228. Lund: Dept. of Linguistics, University of Lund.

Clauss, Walter. 1929. Die Mundart von Uri: Laut- und Flexionslehre. Frauenfeld: Huber.

Dagsgard, Asbjørn. 2006. Målet i Lom og Skjåk. Lom, Skjåk: Lom kommune, Skjåk kommune.

Davis, Stuart. 2003. The controversy over geminates and syllable weight. In The syllable in optimality theory, ed. C. Féry and R. van de Vijver, 77-98. Cambridge: Cambridge University Press.

Downing, Laura. 2006. Canonical forms in prosodic morphology. Oxford: Oxford University Press.

Ekre, Lars. 1960. Opplysningar til stadnamn frå Midt-Jotunheimen. Oslo: Universitetsforlaget.

Fliflet, Albert Lange. 1954. Gudbrandsdalsmålets kvantitetssystemer. Maal og Minne 1954: 52-55.

Gordon, Matthew K. 2006. Syllable weight: Phonetics, phonology, typology. London and New York: Routledge.

Gussenhoven, Carlos. 2009. Vowel duration, syllable quantity, and stress in Dutch. In The nature of the word. Studies in honor of Paul Kiparsky, ed. K. Hanson and S. Inkelas. Cambridge, Massachusetts: The MIT Press.

Gårding, Eva. 1977. The Scandinavian word accents. Lund: CWK Gleerup.

Hannaas, Torleiv. 1921. In Satesdals-måletSetesdalen, ed. G. Rysstad. Kristiania [Oslo]: Cammermeyer.

Harling-Kranck, Gunilla, and Johanna Mara. 1998. Från Pyttis till Nedervetil: tjugonio prov på dialekter $i$ Nyland, Aboland, Aland och Österbotten. Helsingfors: Svenska litteratursällskapet i Finland.

Hayes, Bruce. 1989. Compensatory lengthening in moraic phonology. Linguistic Inquiry 20: 253-306.

Hayes, Bruce. 1995. Metrical stress theory. Chicago: The University of Chicago Press.

Hayes, Bruce. 2003. Why Ranking Software?: http://www.linguistics.ucla.edu/people/hayes/otsoft/why. htm.

Hayes, Bruce, Bruce Tesar and Kie Zuraw. 1993. OTSoft: http://www.linguistics.ucla.edu/people/hayes/ otsoft/.

Hesselman, Bengt. 1902. Stafvelsesförlängning och vokalkvalitet. Undersökningar i nordisk ljudhistoria. Uppsala: Uppsala nya tidnings AB.

Horne, Helga. 1917. Aksent og kvantitet i Vaagaamaalet. Kristiania [Oslo]: H. Aschehoug \& Co.

Hultman, Olof F. 1894. De östsvenska dialekterna. Finländska bidrag till svensk språk- och folklifsforskning, 113-303. Helsingfors: Svenska landsmålsföreningen i Helsingfors.

Hyman, Larry. 1985. A theory of phonological weight. Dordrecht: Foris.

Kager, René. 1999. Optimality theory. Cambridge: Cambridge University Press.

Kiparsky, Paul. 2008. Fenno-Swedish quantity: Contrast in stratal OT. In Rules, constraints, and phonological phenomena, ed. B. Vaux and A. Nevins. Oxford: Oxford University Press. 
Kristoffersen, Gjert. 1990. East Norwegian prosody and the level stress problem. Tromsø: University of Tromsø.

Kristoffersen, Gjert. 2000. The phonology of Norwegian. Oxford: Oxford University Press.

Kristoffersen, Gjert. 2006. Markedness in Urban East Norwegian tonal accent. Nordic Journal of Linguistics 29: 95-135.

Kristoffersen, Gjert. 2007. Jamvektseffekten. En fonetisk analyse av jamvekt i nordgudbrandsdalsdialekten. Norsk Lingvistisk Tidsskrift 25: 187-232.

Kristoffersen, Gjert. 2008. Level stress in North Germanic. Journal of Germanic Linguistics 20: 87-159.

Kristoffersen, Gjert. 2010. Fra jamvekt til etterleddstrykk og tonelag 3: Kvantitetsomleggingen i Ovansiljan. Maal og Minne 2010(2): 1-57.

Kusmenko, Jurij. 1995. Die mittelgermanische Quantitätsverschiebung im Lichte der Daten der modernen germanischen Dialekte. In Quantitätsproblematik und MetrikGreifswalder Symposion zur germanischen Grammatik, ed. H. Fix. Amsterdam: Rodopi.

Küspert, Klaus-Christian. 1988. Vokalsysteme im Westnordischen: Isländisch, Färöisch, Westnorwegisch. Prinzipen der Differenzierung. Tübingen: Max Niemeyer Verlag.

Ladefoged, Peter, and Ian Maddieson. 1996. The sounds of the world's languages. Oxford, UK and Malden, MA.: Blackwell.

Levander, Lars. 1925. Dalmålet. Beskrivning och historia. Appelbergs boktryckeri aktiebolag: Uppsala.

Maddieson, Ian. 1984. Patterns of sounds. Cambridge: Cambridge University Press.

McCarthy, John J. 2002. A thematic guide to optimality theory. Cambridge: Cambridge University Press.

Morén, Bruce. 2000. The puzzle of Kashmiri stress: Implications for weight theory. Phonology 17: 365396.

Morén, Bruce. 2001. Distinctiveness, coercion and sonority: A unified theory of weight. New York: Routledge.

Page, B.Richard. 2001. Hesselman's law, Prokosch's law, and moraic preservation in the Germanic quantity shift. Journal of Germanic Linguistics 13: 231-255.

Pihl, Carin. 1924. Överkalixmålet I. Stockholm: Nordstedts.

Prince, Alan and Paul Smolensky. 2004 [1993]. Optimality theory. constraint interaction in generative grammar. Oxford: Blackwell.

Prokosch, Eduard. 1939. A comparative Germanic grammar. Philadelphia: Linguistic Society of America.

Riad, Tomas. 1992. Structures in Germanic prosody. Stockholm: University of Stockholm doctoral dissertation.

Riad, Tomas. 1995. The quantity shift in Germanic: A typology. Amsterdamer Beiträge zur älteren Germanistik 42: 159-184.

Rice, Curt. 2006. Norwegian stress and quantity: The implications of loanwords. Lingua 116: 1171-1194.

Seiler, Guido. 2009. Sound change or analogy? Monosyllabic lengthening in German and some of its consequences. Journal of Comparative Germanic Linguistics 12: 229-272.

Skomedal, Trygve. 1972. Vokalsystemet i Sætesdalsmålet. In Mål og namn, ed. H. Magerøy and K. Venås. Oslo: Universitetsforlaget.

Skulerud, O. 1918. Telemaalet i umriss. Kristiania [Oslo] hnogh: Norli.

Skulerud, Olai (ed.) 1920. Ordlister over lyd- og formlceren $i$ norske bygdemål af Johan Storm (Videnskapsselskapets Skrifter. II Hist.-Filos. Klasse. 1919. No. 3. Kristiania [Oslo]: Dybwad.

Skulerud, Olai. 1922. Tinnsmaalet. Fyrste bolken I: Ljodlaere. Halle: Max Niemeyer Verlag.

Storm, Johan. 1884. Norvegia. Tidsskrift for det norske folks maal og minder. Kristiania [Oslo]: Grøndahl \& Søn.

Söderström, Sven. 1972. Om kvantitetsutvecklingen i norrländska folkmål. Uppsala: Almqvist \& Wiksell.

Vanvik, Arne. 1972. A phonetic-phonemic analysis of standard Eastern Norwegian, part 1. Norsk tidsskrift for sprogvidenskap 26: 119-164.

Vanvik, Arne. 1973. A phonetic-phonemic analysis of standard Eastern Norwegian, part 2. Norsk tidsskrift for sprogvidenskap 27: 101-139. 